\title{
A PERSEGUIÇÃo ÀS RELIGIÕES AFRO-BRASILEIRAS À LUZ DA TEORIA DAS LUTAS DE CLASSES: UMA ANÁLISE JURÍDICO-LITERÁRIA*
}

\author{
THE RELIGIOUS HARASSMENT OF AFRO-BRAZILIAN CULTS IN THE LIGHT OF THE MARXIST
}

CLASS THEORY: A JURIDICAL-LITERARY ANALYSIS

Fernando Perez da Cunha Lima**

\begin{abstract}
Resumo:
$\mathrm{O}$ presente trabalho tem como norte analisar o fenômeno da intolerância religiosa que origina a perseguição às religiões afro-brasileiras no decorrer dos séculos $\mathrm{XX}$ e XXI. Para tal, o autor faz uso do materialismo histórico dialético e da Teoria das lutas de classes.

Palavras-chave: Marxismo. Materialismo histórico dialético. Religiões afrobrasileiras. Luta de Classes. Umbanda. Candomblé.
\end{abstract}

\begin{abstract}
:
The current paper studies how the harassment of Afro-Brazilian religions leads to massive religious intolerance along the Twentieth and Twenty First Centuries. The author uses the dialectical and historical materialism method and the Marxist class theory in order to achieve his objectives.
\end{abstract}

Keywords: Marxism. Dialectical and historical materialism. Afro-Brazilian Religions. Marxist class theory. Umbanda. Candomblé.

1. Introdução

- Umbé oxirê fum ipacô tô Ijenã, houve uma festa no terreiro de Ijenã. Era festa grande, de Ogum, e veio um mundão de gente ver Ogum dançar. Ogum Aiacá dançou bonito pra alegrar os olhos do povo cansado de sofrer tanto padecimento. Quando estava no melhor de sua dança, chegou sarapebé, o homem do recado, e contou que os soldados vinham vindo com as armas embaladas para acabar com a festa de Ogum e arrasar o terreiro de Ijenã. Vinham galopando nos cavalos, e na pressa de chegar e de bater. Ogum escutou a falação do homem do recado, o aviso que Oxóssi lhe mandava, foi ao mato ali pertinho, assoviou chamando duas cobras, cada

\footnotetext{
Apresentado como trabalho de conclusão de curso na Faculdade de Direito do Largo de São Francisco na data de 18 de novembro de 2015, ante banca composta pelos Professores Ari Marcelo Solon e Marcus Orione Gonçalves Correia.

** Fernando Perez da Cunha Lima é graduando em Direito pela Faculdade de Direito do Largo de São Francisco. 
qual mais comprida e perigosa. Botou as duas no meio da sala, dois novelos de veneno, enrodilhadas, a cabeça para cima, de fora as línguas peçonhentas os olhos assuntando a porta da rua. Em frente à porta, bem do seu, Ogum dançava à espera dos soldados. Não tardou eles chegarem, pulavam dos cavalos, e sem dizer aqui del rei iam puxando as armas de bater e criar bicho. Da porta, Ogum falou assim para os soldados: Quem for de paz entre no terreiro, venha dançar em minha festa. Para os amigos, meu coração é mel de flores, mas ai dos inimigos: pra eles meu coração é poço de veneno. Apontou as duas cobras em seu veneno enrodilhadas, os soldados sentiram medo, mas ordem é ordem e ordem de quartel de polícia é sem pena, sem apelo, sem revogação. Avançaram os soldados contra Ogum, as armas levantadas. Ogum capê dã meji, dã pelu onibã. Ogum chamou as cobras e as cobras se ergueram diante dos soldados. Ogum avisou: quem quiser brigar terá briga, quem quiser guerra terá guerra, as cobras morderão e matarão, não vai ficar nem um soldado vivo. As cobras avançaram as línguas venenosas e aos gritos de socorro os soldados saltaram nos cavalos e fugiram, depressa foram embora, porque em sua dança sem parar Ogum chamou as duas cobras, Ogum capê dã meji, dã pelu onibã.

Pedro Archanjo repetiu: Ogum capê dã meji, dã pelu onibã, a praga imemorial, a terrível ameaça dos males do mundo, das desgraças sem conta sortilégio e imprecação, a derradeira dádiva da Iá. Na cidade, o delegado Pedrito gordo soltara a malta do terror com carta branca: invadir terreiros, destruir pejis, surrar babalaôs e pais de santo, prender feitas e iaôs, iá-quequerês e ialorixás. [... $]^{1}$

Aos 90 anos de idade, morreu Mãe Dede de Iansã, do Terreiro de Oyá.

Mãe Dede não faleceu de morte natural. Foi assassinada, de forma premeditada e cruel.

A ialorixá mais idosa de Camaçari foi mais uma vítima da crescente intolerância religiosa que contamina o país.

Tudo começou há cerca de um ano, quando a bendita "Casa da Oração" resolveu instalar-se nas proximidades do terreiro de candomblé.

Imediatamente após a inauguração, estimulados por pastor Lucas, fiéis da seita evangélica iniciaram rituais de hostilização à casa religiosa e também à mãe Dede.

Comandados pelo fanatismo religioso, desordem pública, ofensas e perseguição a devotos da religião de matriz

AMADO, Jorge. Tenda dos milagres. São Paulo: Cia. das Letras, 2011. p. 206-207. 
africana, passaram a ser uma constante na Rua da Mangueira na localidade de Areias.

A violência gratuita e incessante fez com que o caso fosse parar na polícia. Com o registro de ocorrência na $26^{\mathrm{a}}$ Delegacia de Vila de Abrantes, no último dia 15 de maio, foi determinada audiência para apurar a denúncia de ameaça, injúria e intolerância religiosa.

No entanto, infelizmente, Mãe Dede não conseguiu acompanhar a condenação dos culpados.

Durante a noite do último sábado, 30, e a madrugada de domingo, 31, fanáticos da seita, em transe coletiva, promoveram uma vigília de "Libertação" com o intuito de reforçar as injúrias à sacerdotisa.

Horas a fio, aos berros de "queima essa satanás, liberta senhor, destrói a feitiçaria" integrantes da seita - alucinados - rogaram pragas, ameaças e maldições para a dirigente do centro religioso de cultura africana.

Como resultado, com muito medo e nervosa devido à gravidade dos impropérios - após noites sem dormir - a nonagenária sacerdotisa sofreu infarto do miocárdio e faleceu durante as agressões psicológicas. ${ }^{2}$

Ambos os excertos escolhidos para serem utilizados a título de introdução a este trabalho são retratos fiéis da perseguição e intolerância religiosa que possui como alvo principal as religiões de origem afro-brasileira. Em uma primeira leitura, pode-se chegar à conclusão falsa de que tal quadro foi superado com o advento do Estado Democrático de Direito e, consequentemente, do Estado laico.

Todavia, uma análise mais atenta demonstra que os relatos se encontram separados no tempo por um intervalo de aproximadamente um século. O primeiro trecho foi extraído de um dos romances símbolos da obra de Jorge Amado, Tenda dos Milagres, escrita em 1969, retrata a sociedade baiana, mais especificamente soteropolitana, do início do século XX.

Por sua vez, o segundo excerto foi extraído de uma reportagem publicada no ano de 2015 pelo Portal Geledés, importante meio de comunicação que foge ao monopólio das mídias tradicionais, fazendo um jornalismo militante e livre de preconceitos.

Nota-se, portanto, que durante o curso do século XX e o início do século XXI o quadro discriminatório pouco mudou quanto ao seu alvo, contudo indaga-se acerca da imutabilidade da forma na qual a perseguição se manifesta.

FERRÃO, Marcelo. A intolerância religiosa que mata na Bahia: "Queima essa satanás, liberta Senhor, destrói a feitiçaria”. Revista Livre, Camaçari, jun. 2015. 
Porém, ao se deixar cair os olhos mais demoradamente sobre os retratos, chega-se que a despeito da constância da intolerância, houve mudanças significativas que levaram a repressão do âmbito do Estado para a esfera particular.

A perseguição religiosa, étnica, cultural e principalmente racial ainda se faz presente no cotidiano da sociedade brasileira contemporânea. Não é, portanto, parte superada de nossa história cuja mera lembrança deveria ser suficiente para perturbar a consciência de gerações de brasileiros, permanece atual e atuante e mais ainda, não se nota uma diminuição, ao contrário, observa-se um crescimento.

Inverídico seria argumentar da sua imutabilidade, indaga-se acerca das diferenças e características específicas, sua evolução, o modo que se dava e que se dá e as consequentes reações sociais a tais fenômenos, no passado no presente. São alguns dos questionamentos aos quais este trabalho se propõe a responder, ou ao menos, indicar um possível caminho para se obter indícios de respostas.

Não se pode conceber a ideia de responder tais questionamentos sem se pensar na dinâmica da luta de classes, portanto, se faz como um dos objetivos principais do presente estudo compreender de como favorece os interesses da burguesia que se mantenha uma aparência de liberdade e de laicidade do Estado, quando, em verdade, vive-se em uma sociedade amplamente intolerante e preconceituosa.

De sorte que para a total compreensão do fenômeno, mister é que faça uma breve introdução às teorias marxistas.

\section{Luta de classes}

O estudo da luta de classes para o correto entendimento do tema da intolerância religiosa se faz de grande importância na medida em que a teoria da luta de classes se coloca como Teoria geral do conflito social.

Karl Marx e Friedrich Engels no clássico Manifesto do Partido Comunista enunciam o grande predicado da teoria da luta de classes, "Até hoje, a história de toda sociedade é a história das lutas de classes". ${ }^{3}$ Ora, que implicações tal afirmação é capaz de gerar? Em uma primeira análise, tira-se o foco do indivíduo como força motriz da história, supera-se a ideia de que o que faz os acontecimentos históricos são as vontades individuais e suas atitudes que eram vistas, nos dizeres da sabedoria francesa, como um raio em um céu azul.

MARX, Karl; ENGELS, Friedrich. Manifesto do partido comunista. São Paulo: Penguin Classics Cia. das Letras, 2012. p. 44. 
Tem-se, portanto, na luta de classes o propulsor do trem da história. Contudo, dúvidas pairam quanto a sua essência, o que seria a luta de classes? De que forma ela se manifesta? Permanece sendo a mesma desde os tempos da elaboração do Manifesto?

Busca-se auxílio no grande autor italiano Domenico Losurdo para propor soluções para tais questionamentos. Afirma ele que: "[a luta de classes] entre proletariado e burguesia é apenas uma das lutas de classes e que estas, cruzando em profundidade a história universal, não são de modo nenhum característica exclusiva da sociedade burguesa e industrial. Se ainda persistirem dúvidas, algumas páginas depois, o Manifesto reafirma: 'A história de toda sociedade até nossos dias moveu-se em antagonismos de classes, antagonismos que se têm revestido de formas diferentes nas diferentes épocas'. Portanto, não apenas as 'lutas de classes' a ser declinadas no plural, mas também as 'formas' que elas assumem nas diversas épocas históricas, nas diferentes sociedades, nas diferentes situações concretas que progressivamente surgem. Quais são as múltiplas lutas de classes, ou seja, as múltiplas configurações da luta de classes?"

Nota-se, portanto, que na visão do italiano, a luta de classes não é uma característica somente da sociedade capitalista burguesa, entende que a luta de classes é uma constante em toda a história. Contudo, análises apressadas e desatentas do processo histórico não permitem a correta localização do fenômeno, uma vez que a luta de classes possui diversas formas de se manifestar de acordo com o contexto histórico no qual ela se insere. Portanto, não haveria "luta de classes", mas "lutas de classes", no plural, sem que, no entanto, o plural indique a mera repetição de formas. ${ }^{5}$ De sorte que o uso do plural não é mero acaso ou capricho literário e estilístico, possui grandes inclinações, uma das quais é a de que a luta de classes é capaz de mutações e pode assumir as formas mais distintas.

Que formas e configurações seriam essas que as lutas de classes assumiriam? Responde Losurdo que a luta de classes assume três configurações, a saber: a luta travada entre burguesia e proletariado; a luta entre países de origem colonial ou "subdesenvolvidos" em oposição aos da metrópole, os "desenvolvidos"; e, finalmente a luta pela emancipação da mulher na sociedade machista e patriarcal na qual se vive. Neste sentido, mister é que se cite um importante trecho da obra de tal autor reservada para o tema: "a luta de classes que tem como protagonistas os povos em condições coloniais ou

LOSURDO, Domenico. A luta de classes: uma história política e filosófica. São Paulo: Boitempo Editorial, 2015. p. 15.

5 "o plural não quer denotar a repetição do idêntico, o contínuo recorrer à mesma fórmula da mesma luta de classes; não, o plural remete à multiplicidade das configurações que a luta de classes pode assumir". LOSURDO, Domenico. A luta de classes: uma história política e filosófica. São Paulo: Boitempo Editorial, 2015. p. 29. 
semicoloniais ou de origem colonial; a luta travada pela classe operária nas metrópoles capitalistas; a luta das mulheres contra a escravidão doméstica". ${ }^{6}$

Explanar-se-á, agora, individualmente cada configuração das lutas de classes, uma vez que tal conhecimento será de extrema importância para o desenvolvimento do estudo que ora se desenvolve.

Abordar-se-á, em um primeiro momento, a configuração dita "clássica" das lutas de classes e que foi a mais estudada por Marx e Engels, trata-se da luta de classes travada entre proletariado e burguesia.

Convoca $O$ Manifesto do Partido Comunista, em sua mais célebre frase à união do proletariado mundial contra a burguesia, para que se possa, finalmente, romper com os grilhões da servidão, da servidão assalariada e do domínio do Capital. ${ }^{7}$

O homem livre e escravo, patrício e plebeu, senhor e servo, mestre de corporação e aprendiz - em suma, opressores e oprimidos sempre estiveram em oposição, travando uma luta ininterrupta, ora velada, ora aberta, uma luta que sempre terminou ou com a reconfiguração revolucionária de toda sociedade ou com o ocaso conjunto das classes em luta. ${ }^{8}$

Coloca-se, portanto a luta entre o proletariado e a burguesia como sendo presente em todos os momentos conhecidos da história, contudo não seria verossímil assumir que a oposição proletariado x burguesia permaneceu estanque no tempo e inabalável pelo decurso da história e suas mudanças sociais. Sabe-se que a sociedade burguesa surgiu após o colapso da sociedade feudal, que por si só já possuía seus antagonismo de classes e mecanismos de opressão próprios, nada mais fez, portanto, a sociedade burguesa do que trazer à baila da história novas classes e novos e mais sofisticados métodos de opressão, muitas vezes velada, passando a ilusão de liberdade e igualdade reinantes.

Todavia, a sofisticação dos métodos de opressão é fruto, na verdade, de uma simplificação do sistema de classes sociais. Ao se observar as sociedades que precederam a sociedade burguesa, pode-se encontrar uma quantidade muito maior de estamentos. Têmse na Roma Antiga, por exemplo, os patrícios, cavaleiros, plebeus, escravos; na idade

LOSURDO, Domenico. A luta de classes: uma história política e filosófica. São Paulo: Boitempo Editorial, 2015. p. 64.

7 "Os comunistas repudiam todo e qualquer ocultamento de suas posições e intenções. Eles declaram abertamente que seus propósitos só podem ser alcançados mediante a derrubada pela força de toda ordem social até hoje reinante. Que as classes dominantes tremam ante a revolução comunista. Os proletários nada mais têm a perder com ela do que seus grilhões. Têm, sim, um mundo a ganhar.

PROLETÁRIOS DE TODOS OS PAÍSES, UNAM-SE!”. MARX, Karl; ENGELS, Friedrich. Manifesto do partido comunista. São Paulo: Penguin Classics Cia. das Letras, 2012. p. 83.

8 MARX, Karl; ENGELS, Friedrich. Manifesto do partido comunista. São Paulo: Penguin Classics Cia. das Letras, 2012. p. 44. 
média sevos aprendizes, mestres de corporação, senhores feudais e seus vassalos. Por sua vez, na sociedade burguesa há somente uma divisão, entre proletariado e burguesia. ${ }^{9}$

Têm-se, portanto, na burguesia uma classe amplamente revolucionária, visto que revolucionou e revoluciona constantemente, como condição para sua existência, as relações de produção, tal a importância desta afirmação que irá se recorrer às fontes para a sua melhor compreensão:

Em resumo, a burguesia trocou a exploração envolta em ilusões religiosas e políticas pela exploração pura e simples, aberta, desavergonhada e direta.

Todas aquelas atividades desde sempre encaradas com temor respeitoso e devoto, a burguesia as despiu de sua auréola. Ela transformou o médico, o jurista, o sacerdote, o poeta o homem das ciências em assalariados a seu serviço. A burguesia removeu das relações familiares o véu emotivosentimental, reduzindo-as a mera relação monetária.

A burguesia revelou com dispêndio brutal de forças, que a reação tanto admira na idade média, encontrou seu complemento adequado na mais indolente ociosidade. Somente ela demonstrou o que a atividade humana é capaz de produzir. Erigiu maravilhas muito diferentes das pirâmides egípcias, dos aquedutos romanos e das catedrais góticas, e promoveu marchas bastante diversas das migratórias ou daquelas das Cruzadas.

Aburguesia não pode existir sem revolucionar continuamente os instrumentos de produção - ou seja, as relações de produção - isto é, o conjunto das relações sociais. A manutenção inalterada do velho modo de produção era, ao contrário, condição primordial para a existência de todas as classes industriais anteriores. A transformação contínua da produção, o abalo ininterrupto de todas as condições sociais, incerteza e movimentos eternos, eis aí as características que distinguem a época burguesa de todas as demais. ${ }^{10}$

Tem-se que em sua busca por satisfazer sua necessidade constante e crescente de escoamento de seus produtos levou a uma grande expansão de seus vínculos, ocasionando o surgimento do chamado mercado mundial. Todavia, para que a expansão do escoamento de sua produção possa ocorrer a burguesia deve, primeiramente, lutar contra a fragmentação dos meios de produção, da propriedade e das populações. De sorte

9 MARX, Karl; ENGELS, Friedrich. Manifesto do partido comunista. São Paulo: Penguin Classics Cia. das Letras, 2012. p. 44 e 45.

10 MARX, Karl; ENGELS, Friedrich. Manifesto do partido comunista. São Paulo: Penguin Classics Cia. das Letras, 2012. p. 46 e 47. 
que se centralize os meios de produção e se concentre a produção, chegando-se em última instância à centralização política. ${ }^{11}$

Após tal breve inserção nos modos de produção que foram predecessores do capitalismo, extrai-se que a sociedade feudal gestou o embrião da sociedade capitalista na medida em que os seus meios de produção e de circulação forneceram a base para o surgimento da burguesia. De sorte que houve um amplo desenvolvimento de tais meios de produção e circulação até se atingir o patamar no qual as relações feudais de propriedade se tornaram incompatíveis com as forças de produção desenvolvidas. Ora, se foi atingido um nível de incompatibilidade entre relações de propriedade e forças de produção que se mostrou inconciliável, pode-se dizer que ao invés de estimular a produção, as relações de propriedade a inibiam, de modo que o crescimento da produção só seria possível se se superassem as formas feudais de produção.

Eis que surge a figura da livre concorrência em companhia de constituições sociais e políticas adequadas a classe burguesa. ${ }^{12}$

Até o presente momento, estudou-se, somente, o surgimento e o desenvolvimento da classe burguesa, todavia pouco se falou de seu oposto indissociável, o proletariado. Sabe-se que o desenvolvimento da burguesia - isto é do Capital - ocasiona impreterivelmente o desenvolvimento da classe proletária, dos trabalhadores modernos. Uma característica fundamental de tal existência conjunta é o fato de que os trabalhadores, por não serem detentores dos meios de produção, dependem única e exclusivamente da sua força de trabalho para obtenção de seu sustento material. Para tal, necessário é que eles encontrem a quem vender a sua força de trabalho e só encontram trabalho na medida em que seu próprio trabalho multiplica o capital. Logo, não é surpresa alguma afirmar que o crescimento do Capital é sustentado pela força de trabalho do proletariado.

Devido a sua necessidade insuperável de venda da força de trabalho, o próprio trabalhador acaba se transformado em mercadoria. Em tal sentido, fornecem Marx e Engels, importante ensinamento ao dizer que:

O trabalhador torna-se mero acessório da máquina, do qual se exige apenas o mais simples e monótono movimento da mão, de aprendizado facílimo. Os custos que o trabalhador acarreta restringem-se, assim, quase que tão somente aos dos víveres de que ele necessita para seu sustento e para a propagação de sua espécie. O preço de uma mercadoria,

11 MARX, Karl; ENGELS, Friedrich. Manifesto do partido comunista. São Paulo: Penguin Classics Cia. das Letras, 2012. p. 48-50.

12 MARX, Karl; ENGELS, Friedrich. Manifesto do partido comunista. São Paulo: Penguin Classics Cia. das Letras, 2012. p. 50-51. 
porém, e portanto do trabalho, é igual ao de seus custos de produção. ${ }^{13}$

Para que o proletariado possa vender sua força de trabalho é necessário, por óbvio, que possua condições mínimas para prover sua existência e para que possa se reproduzir e com isso aumentar o contingente de força de trabalho disponível - de sorte que se a oferta de trabalhadores for maior que a demanda da produção, os salários diminuem e o nível de exploração aumenta -, de modo que o preço mínimo da força de trabalho é aquele necessário para a manutenção e reprodução da vida do trabalhador, para sua subsistência, o necessário para que se sobreviva e se reproduza. ${ }^{14}$

Juntamente com o surgimento do proletariado, há o nascimento de sua oposição à burguesia. Há diversos estágios de desenvolvimento da oposição burguesia $\mathrm{x}$ proletariado. Evidencia-se, fundamentalmente, três estágios de tal luta.

Nas primeiras oportunidades de manifestação do proletariado, nota-se sua grande fragmentação pela concorrência, de sorte que seus combates se dão ante os resquícios da monarquia absoluta, favorecendo, de tal forma, a burguesia. Contudo, o próprio desenvolvimento industrial aumenta a concorrência dentro da classe burguesa, minando a sua união que era a causa da desunião proletária, favorecendo os movimentos dos trabalhadores, todavia permanecem ainda como conflitos isolados apesar do aumento do caráter de colisão entre duas classes.

13 MARX, Karl; ENGELS, Friedrich. Manifesto do partido comunista. São Paulo: Penguin Classics Cia. das Letras, 2012. p. 51.

14 "Até hoje, como vimos, todas as sociedades sempre se assentaram na oposição entre as classes opressoras e oprimidas. Contudo, para que uma classe possa ser oprimida, é preciso que lhe sejam asseguradas condições sob as quais ela possa ao menos levar uma existência servil. O servo, em sua servidão, fez-se membro da comuna, assim como sob o jugo do absolutismo feudal, o pequeno-burguês se transformou em burguês. O trabalhador moderno, ao contrário, em vez de se erguer com o progresso da indústria, afunda cada vez mais, abaixo das condições de sua própria classe. O trabalhador se transforma em miserável, e a miséria desenvolve-se com rapidez ainda maior que a população ou a riqueza. Evidencia-se, assim, claramente que a burguesia é incapaz de se manter por mais tempo como a classe dominante e de impor a ela, como lei reguladora, as condições de vida da sua classe. Ela é incapaz de dominar em razão da sua incapacidade de assegurar a seu escravo até mesmo uma existência no interior dessa escravidão, vendo-se obrigada a rebaixá-lo a uma condição, na qual, em vez de se alimentar dele, precisa alimentá-lo. A sociedade não pode viver sob ela, ou seja, a vida da burguesia deixa de ser compatível com a sociedade.

A condição essencial para a existência e a dominação da classe burguesa é a acumulação da riqueza em mãos privadas, a formação e a multiplicação do capital; a condição para o capital é o trabalho assalariado. $\mathrm{O}$ trabalho assalariado, por sua vez, se assenta exclusivamente na concorrência entre os trabalhadores. $\mathrm{O}$ progresso da indústria, de que a burguesia - sem o desejar e sem opor resistência a ele - é pilar, põe no lugar do isolamento pela concorrência a união revolucionária dos trabalhadores em associações. Assim, o desenvolvimento da grande indústria tira da burguesia o próprio chão sobre o qual ela produz e se apropria de produtos. O que ela produz é, sobretudo, seu próprio coveiro. Sua derrota e a vitória do proletariado são, ambas, inevitáveis.”. MARX, Karl; ENGELS, Friedrich. Manifesto do partido comunista. São Paulo: Penguin Classics Cia. das Letras, 2012. p. 57- 58. 
Na medida em que o proletariado vai adquirindo consciência de classe, sua união e, consequentemente, sua força crescem e os combates travados ante a burguesia assumem caráter transformador.

Entende-se que a breve inserção na configuração da luta de classes entre proletariado e burguesia se faz suficiente para a sua compreensão no quadro da intolerância religiosa.

2.1. A luta de classes das nações oprimidas

Para que se possa fazer tal estudo, necessário é que se delimitem as categorias nas quais se procederá com a alocação das Nações.

Nos dizeres de Moreno,

Dependente é o país que politicamente é independente, isto é, elege seus governantes, mas desde o ponto de vista dos empréstimos, do controle do comércio ou da produção, depende, economicamente, de uma ou várias potências imperialistas. Semicolonial é aquele que assinou pactos de tipo político ou econômico que cerceiam sua soberania, sem perdê-la totalmente. E colonial é aquele que nem sequer elege seu governo, já que o mesmo é imposto ou controlado por país um país imperialista (MORENO, 1975, p. 90 apud ARCARY, 2014, p. 153). ${ }^{15}$

Excelente classificação para descrever a atualidade da configuração geopolítica internacional, coloca no critério da soberania aliado com a dependência econômica e mesmo política o critério de classificação. Contudo, não se mostra a classificação mais adequada para o estudo que aqui se propõe.

Entende-se que as melhores categorias para serem utilizadas são aquelas as quais faz uso o historiador e filósofo Domenico Losurdo, quais sejam: Nações Opressoras e Nações Oprimidas, bastantes simples, porém não simplistas, os termos são autoexplicativos.

Apesar de sua grande contribuição para o tema, não foi Losurdo o primeiro a colocar o conflito entre as nações como oposição entre opressores e oprimidos.

Novamente, volta-se aos clássicos e invoca-se, novamente, O Manifesto.

“À medida que se abolir a exploração de um indivíduo pelo outro, abolirse-á também a exploração de uma nação pela outra." ${ }^{16}$ Nota-se, portanto que o combate

15 ARCARY, Valério. Um reformismo quase sem reformas. Uma crítica marxista do governo Lula em defesa da revolução brasileira. São Paulo: Editora Sundermann, 2014. p. 153.

16 MARX, Karl; ENGELS, Friedrich. Manifesto do partido comunista. São Paulo: Penguin Classics Cia. das Letras, 2012. p. 66. 
à exploração do proletariado é corolário do combate à exploração das nações. Contudo, levanta-se o questionamento acerca da veracidade do inverso, ao se combater a exploração das nações, combater-se-á, necessariamente, a exploração do proletariado? A resposta para tal indagação foge ao tema do presente trabalho, razão pela qual se recomenda a leitura da obra "A luta de classes: uma história política e filosófica" do italiano Domenico Losurdo.

Portanto, tem-se que Nações opressoras são aquelas que tal qual a burguesia sustentam seu crescimento e seu desenvolvimento na exploração de outras nações, as nações oprimidas. Logo, tem-se que a revolução conclamada por Marx e Engels não busca somente a libertação do proletariado, nos dizeres de Losurdo:

a revolução radical invocada por Marx e Engels não persegue apenas libertação/emancipação da classe oprimida (o proletariado), mas também a libertação/emancipação das nações oprimidas. ${ }^{17}$

Ademais, Marx preconiza que aqueles que não conseguem compreender como um país pode enriquecer à custa de outros, não conseguirão entender de que modo no interior de um país singular uma classe pode enriquecer à custa de uma outra, de sorte que compreensão do fenômeno da exploração e da opressão que se desenvolvem no plano internacional são uma condição necessária para que se compreenda o conflito intranacional entre burguesia e proletariado. ${ }^{18}$

\begin{abstract}
Junto com a 'libertação', ou seja, a 'emancipação econômica do proletariado', Marx e Engels reivindicam, como se sabe, a 'libertação', isto é, a 'emancipação' das 'nações oprimidas'. É luta de classes aquela que aponta à libertação/ emancipação das classes exploradas, mas não aquela que se propõe conseguir a libertação/emancipação das nações exploradas e (oprimidas)? É luta de classes aquela que tem como protagonista uma classe que conseguiu emancipação política, mas não econômica e social, ao passo que não seria luta de classes a luta conduzida por uma nação que está aquém da própria emancipação política? ${ }^{19}$
\end{abstract}

O estudo da obra de Marx permite afirmar que o alemão entendia que sim, que o conflito pela emancipação/libertação das nações oprimidas é luta de classes.

\footnotetext{
17 LOSURDO, Domenico. A luta de classes: uma história política e filosófica. São Paulo: Boitempo Editorial, 2015. p. 20.

18 “a exploração e a opressão que se desenvolvem em âmbito internacional são uma precondição, pelo menos no plano metodológico, para a compreensão do conflito social e da luta de classes em âmbito nacional". LOSURDO, Domenico. A luta de classes: uma história política e filosófica. São Paulo: Boitempo Editorial, 2015. p. 26.

19 LOSURDO, Domenico. A luta de classes: uma história política e filosófica. São Paulo: Boitempo Editorial, 2015. p. 26.
} 
Contudo, deve-se atentar ao fato de que: "Se o proletariado é o protagonista do processo de libertação/emancipação que arrebenta os grilhões do domínio capitalista, o campo chamado a quebrar os grilhões da opressão nacional é mais amplo", ${ }^{20}$ de sorte que pode se haver alianças com a burguesia nacional visando à emancipação/libertação das nações oprimidas, ensejando no fato de que nem todas as lutas pela emancipação nacional são lutas anticapitalistas. Ao analisar a conjuntura global no pós Segunda Guerra, Valério Arcary afirma que:

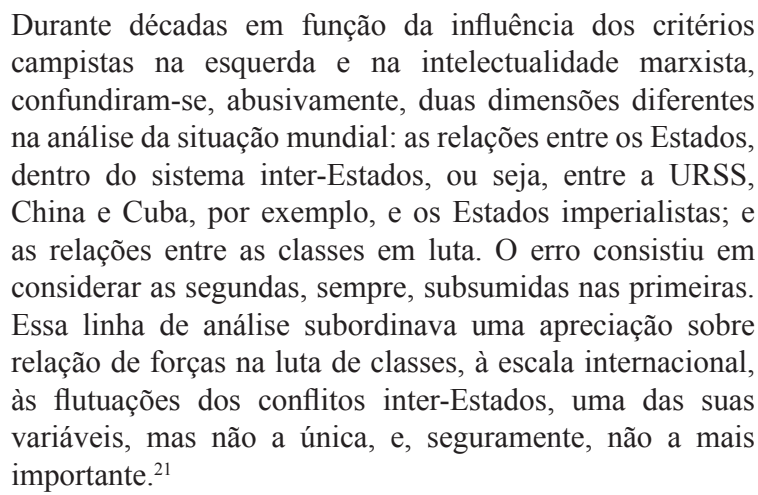

Conclui-se, portanto, que a luta pela emancipação/libertação das nações oprimidas é uma das configurações possíveis das lutas de classes, mas que, no entanto, não se pode olvidar da conjuntura da luta de classes entre proletariado e burguesia.

\subsection{Luta pela emancipação das mulheres}

Chega-se, agora, ao momento de maior dificuldade do desenvolvimento da teoria das lutas de classes. Explanar-se-á a luta pela emancipação da mulher. Todavia, por se tratar o autor de um homem, resta impossível a correta compreensão do fenômeno. Razão pela qual não se fará grandes inserções no tema, apesar de sua importância fundamental.

Sabe-se que se vive em uma sociedade patriarcal e extremamente machista, na qual a mulher é forçada a cumprir jornadas de trabalho extenuantes e receber por isso menos que os homens que executam os mesmos ofícios e ainda lhe é imposta a total responsabilidade pelos afazeres domésticos, implicando em jornadas de trabalho duplas ou, até mesmo, triplas. Diz Marx que o burguês não vê em sua esposa mais do que um

20 LOSURDO, Domenico. A luta de classes: uma história política e filosófica. São Paulo: Boitempo Editorial, 2015. p. 21.

21 ARCARY, Valério. Um reformismo quase sem reformas. Uma crítica marxista do governo Lula em defesa da revolução brasileira. São Paulo: Editora Sundermann, 2014. p. 153. 
meio de produção, em tal aspecto se discorda de Marx, pois não é só o burguês que se vale da exploração do trabalho feminino (seja ele doméstico ou fabril), o proletariado também se beneficia, na medida em que não toma para si as responsabilidades do trabalho doméstico e não divide as responsabilidades da casa e da sua família. ${ }^{22}$ Ademais, afirmase que a instituição do patriarcado marcou a derrota histórica do sexo feminino, que foi transformado em servo do sexo masculino, degradando a mulher à servidão doméstica, a escravidão da lascívia e a condição de mero instrumento para a produção de filhos. ${ }^{23}$

Importante visão é a de Domenico Losurdo que coloca a relação homem/ mulher como sendo um microcosmo da totalidade da sociedade, na qual o homem representaria o burguês que explora o proletariado, encarnado na figura da mulher, ${ }^{24} \mathrm{de}$ sorte que "a emancipação feminina constitui 'a medida da emancipação universal"”.

Conclui-se, portanto, que a moderna família nuclear é fundada na escravidão doméstica da mulher, a qual para que se faça a verdadeira Revolução deve ser a primeira a romper com os grilhões da servidão, que podem a atingir nas três configurações da luta de classes, sendo, de tal forma, a maior vítima da sociedade capitalista.

\section{Religiões Afro-Brasileiras}

Para que se possa compreender os processos de intolerância religiosa, suas motivações e implicações, necessário é que se entenda minimamente os cultos afrobrasileiros, suas liturgias e seus símbolos.

Pode-se citar como sendo as duas mais significativas formas de religiosidade afro-brasileiras, o Candomblé e a Umbanda. Dar-se-á maior ênfase a segunda, por se tratar do maior alvo de perseguição religiosa e por possuir elementos mais interessantes à análise.

\subsection{Candomblé}

Os orixás podiam de novo conviver com os mortais. Os orixás estavam felizes. Na roda das feitas, no corpo das iaôs,

22 “o burguês vê em sua esposa um mero instrumento de produção" MARX, Karl; ENGELS, Friedrich. Manifesto do partido comunista. São Paulo: Penguin Classics Cia. das Letras, 2012. p. 65.

23 "A derrubada do matriarcado marcou a derrota histórica do sexo feminino em todo o mundo. O homem assumiu também o comando da casa; a mulher foi degradada e reduzida à servidão; tornou-se escrava da lascivía e mero instrumento para produção dos filhos" LOSURDO, Domenico. A luta de classes: uma história política e filosófica. São Paulo: Boitempo Editorial, 2015. p. 33.

24 "a emancipação feminina constitui 'a medida da emancipação universal'. No bem e no mal, a relação homem/mulher é uma espécie de microcosmo que reflete a ordem social global" LOSURDO, Domenico. $A$ luta de classes: uma história política e filosófica. São Paulo: Boitempo Editorial, 2015. p. 30. 
eles dançavam e dançavam e dançavam. Estava inventado o

Candomblé. (PRANDI, 2001)

Trata-se da interpretação brasileira da religião dos Orixás que se constituiu no século XIX, portanto, nasce em meio à escravidão e, como tal, surge como uma instituição que opõe resistência a colonização cultural dos negros, à escravidão e aos mecanismos de dominação social impostos pela sociedade escravocrata.

No entanto, ao contrário da Umbanda, o Candomblé veio de terras distantes, veio juntamente com os escravos nos porões dos navios negreiros. A violência que a sociedade escravocrata impunha não se limitava a violência física, extrapolava seus limites, era também violência psicológica e dominação cultural. De modo que para a sobrevivência de sua religiosidade ante a imposição do catolicismo, os negros escravos se viram obrigados a adotar nomes de Santos católicos que apresentassem alguma semelhança com o mito de seus Orixás, como meio de preservar sua cultura e religiosidade. Desse modo que Iansã se transformou em Santa Bárbara, Ogum em São Jorge, Oxóssi em São Sebastião, Iemanjá em Nossa Senhora dos Navegantes e Oxalá em Jesus Cristo, entre tantos outros Orixás. ${ }^{25}$

Ademais, segundo Jensen:

os escravos africanos eram proibidos de praticar suas várias religiões. A Igreja Católica Romana deu ordens para que os escravos fossem batizados e eles deveriam participar da missa e dos sacramentos. Apesar das instituições escravagistas e da Igreja Católica Romana, entretanto, foi possível ao escravo comunicar, transmitir e desenvolver sua cultura e tradições religiosas. Houve vários fatos que os ajudaram a manter esta continuidade: os vários grupos étnicos continuaram com sua língua materna; havia um certo número de líderes religiosos entre eles; e os laços com a África eram mantidos pela chagada constante de novos escravos. (JENSEN, 2001, p. 2).

De sorte que diante de tal quadro opressivo não há muitos registros escritos dos mitos dos Orixás como eram contados à época - antes da influência católica - e da

25 "O culto candomblista teve origem na cidade de Ifé, na África, ao sudoeste da atual Nigéria e chegou as terras pertencentes a Portugal, como no caso do Brasil colônia lusa à época, entre os séculos XVI e XIX e acompanhou toda a trajetória da escravidão. Nessa época, os colonizadores achavam que o rito era baseado na feitiçaria e que tudo que fosse produzido nele era obra do demônio. Por essa razão, a maioria dos praticantes adotou elementos do catolicismo romano, para disfarçar sua crença e não ser reprimidos ou duramente castigados pelos seus senhores. Era uma estratégia de ao mesmo tempo se proteger e resistir à dominação ao tentar preservar de forma disfarçada as suas tradições milenares". SILVA, Francisco Thiago. Candomblé Iorubá: a relação do homem com seu orixá pessoal. Último Andar - Cadernos de Pesquisa em Ciência da Religião, São Paulo, n. 21, p. 48-73, 2013. p. 53. Disponível em: <http://revistas.pucsp.br/index. php/ultimoandar/article/view/13984/10290>. 
história de luta e resistência dos primeiros terreiros. Desempenha, portanto, um papel de protagonismo a tradição oral, mantida principalmente pelas mulheres mais velhas do terreiro que as transmitem aos mais jovens.

Como não há unicidade de registro ou um livro único a ser seguido, o Candomblé é uma forma de religiosidade na qual não há uma forma propriamente unificada de liturgia e culto, havendo diferenças conforme a linha, o terreiro e a região.

No entanto, há aspectos comuns. Entre eles está o culto aos Orixás - todavia, há diferenças entre o culto aos Orixás praticados no Brasil, na África e em Cuba -, do ponto de vista da cosmologia, todos os terreiros cultuam uma espécie de energia universal, o Axé. ${ }^{26} \mathrm{O}$ define, Reginaldo Prandi, como sendo:

Axé é força vital, energia, princípio da vida, força sagrada dos orixás... Axé é bênção, cumprimento, votos de boa-sorte e sinônimo de Amém... Axé se tem, se usa, se gasta, se repõe, se acumula. Axé é origem, é a raiz que vem dos antepassados, é a comunidade do terreiro. Os grandes portadores de axé, que são as veneráveis mães e os veneráveis pais-de-santo, podem transmitir axé pela imposição das mãos; pela saliva, que com a palavra sai da boca; pelo suor do rosto. ${ }^{27}$

Controversa é a questão do caráter politeísta ou não do Candomblé e tal questão é indissociável de divergências quando ao mito da criação do mundo. Há autores que defendem o mito de que foram os Orixás, a mando de Olodumaré que seria um Deus supremo, que criaram o mundo, sendo, de tal forma, politeísta. ${ }^{28}$ Nos dizeres de Prandi:

os orixás são deuses que receberam de Olodumaré ou Olorum, também chamado Olofim em Cuba, o Ser Supremo, a incumbência de criar e governar o mundo, ficando cada um deles responsável por alguns aspectos da natureza e certas dimensões da vida em sociedade e da condição humana. (PRANDI, 2001, p. 524-528).

Por sua vez, a corrente monoteísta, que possui em Pierre Verger seu principal expoente, entende o mito da criação como sendo obra somente de Olorum, que criou também os Orixás. Nesse sentido:

acima dos orixás reina um deus supremo, Olodumaré cuja etimologia é duvidosa. É um deus distante, inacessível e indiferente às preces e ao destino dos homens. Está fora do

\footnotetext{
26 JANSA, Tomáš. Candomblé: as origens, desenvolvimento, transformações e seu papel no decorrer do tempo. Olomouc: [s.n.], 2010. Disponível em: <https://theses.cz/id/swyq85/Tom_Jansa_-_bakalsk_prce.pdf >.

27 PRANDI, Reginaldo. Herdeiras do Axé. São Paulo: Editora Hucitec, 1996- p. 5.

28 SILVA, Francisco Thiago. Candomblé Iorubá: a relação do homem com seu orixá pessoal. Último Andar - Cadernos de Pesquisa em Ciência da Religião, São Paulo, n. 21, p. 48-73, 2013. Disponível em: <http:// revistas.pucsp.br/index.php/ultimoandar/article/view/13984/10290>.
} 
alcance da compreensão humana. Ele criou os orixás para governarem e supervisionarem o mundo. É, pois, a eles que os homens devem dirigir suas preces e fazer oferendas. Olodumaré, no entanto, aceita julgar as desavenças que possam surgir entre os orixás. (VERGER, 2001, p. 11).

De sorte que não é possível se definir o Candomblé por tal critério. Continuando o estudo de tal forma de religiosidade, afirma-se que a ligação com o sagrado se dá por intermédio do Babalorixá (homem) ou da ialorixá (mulher), pais ou mães de Santo. Que são responsáveis, também, por manter e renovar o axé.

Afirma Francisco Thiago Silva que:

O candomblé baseia-se no culto aos orixás, deuses oriundos das quatro forças da natureza: Terra, Fogo, Água e Ar. Os orixás são, portanto, forças energéticas, desprovidas de um corpo material. Sua manifestação básica para os seres humanos se dá por meio da incorporação durante as cerimônias.

Há, portanto, as forças energéticas que não possuem um corpo material e se manifestam durante as cerimônias por meio da incorporação nos iniciados. ${ }^{29}$ Através do culto aos orixás e o estudo de seus mitos, passa-se a cultuar, também, as forças da natureza com ele correlatas.

Neste ponto, entende-se por suficientemente caracterizado o Candomblé. Contudo, a análise aqui feita não se propõe ao esgotamento do tema, havendo muitos aspectos que não foram descritos e analisados por não se entender como pertinentes ao objetivo que se propõe o presente trabalho.

De modo que, proceder-se-á com o estudo da Umbanda.

\subsection{Umbanda}

O autor não pode iniciar seu estudo acerca da Umbanda e de seu mito fundador sem antes agradecer ao Professor Vagner Gonçalves da Silva, do Departamento de Antropologia da Universidade de São Paulo por ter dado a oportunidade de em um trabalho de campo no Santuário Nacional da Umbanda ouvir de Pai Ronaldo o mito fundador da Umbanda que ele, por sua vez, ouviu diretamente de Zélio de Moraes.

\footnotetext{
29 No candomblé, emblematicamente, quando o filho-de-santo entra em transe e incorpora um orixá, assumindo sua identidade representada pela dança característica que lembra as aventuras míticas dessa divindade, é o passado remoto, coletivo, que aflora no presente para se mostrar vivo, o transe ritual repetindo o passado no presente, numa representação em carne e osso da memória coletiva. PRANDI, Reginaldo. Mitologia dos Orixás. São Paulo: Cia. das Letras, 2001. p. 7.
} 
Há grande controvérsia acerca da origem da Umbanda. Todavia, a corrente predominante é aquela que afirma que a Umbanda nasceu em 15 de Novembro de 1908 em São Gonçalo, Rio de Janeiro, com a primeira manifestação do Caboclo das Sete Encruzilhadas através do médium Zélio de Moraes. Diz a história que Zélio, então com 17 anos, apresentava por vezes comportamentos que fugiam a normalidade e que com a mesma surpresa que se manifestavam, se esvaiam. Após relatar o ocorrido a um colega, o pai de Zélio foi orientado a o levar a Federação Espírita, onde ocorreu a primeira manifestação do Caboclo das Sete Encruzilhadas que teria proferido as seguintes palavras:

Se julgam atrasados esses espíritos dos pretos e dos índios, devo dizer que amanhã estarei em casa desse aparelho, para dar início a um culto em que esses pretos e esses índios, poderão dar a sua mensagem e, assim, cumprir a missão que o plano espiritual lhes confiou. Será uma religião que falará aos humildes, simbolizando a igualdade que deve existir entre todos os irmãos, encarnados e desencarnados. E, se querem saber o meu nome, que seja este: Caboclo das Sete Encruzilhadas, porque não haverá caminhos fechados para mim. (AZEVEDO, 2007, p. 19).

Extrai-se do que seria a primeira manifestação umbandista o quadro de preconceito e elitização que predominava no ambiente kardecista. Por se tratar do início do século XX, a difusão das ideias pelo globo era mais lenta e dificultosa, de modo que só a elite brasileira que era capaz de arcar com as grandes despesas de uma viagem à Europa que entrou em contato com as ideias de Allan Kardec e as trouxe para o território pátrio. De modo que os preconceitos de tal elite dominante se sobrepujaram da esfera material e contaminaram os cultos espirituais, não permitindo a manifestação de pretos-velhos e caboclos (índios), por estenderem o seu preconceito terreno ao mundo espiritual.

Deve-se pontuar, ainda, que a presença de guias como os Pretos-Velhos e os Caboclos é importante elemento diferenciador da Umbanda. Pode-se citar como outras guias com as quais a Umbanda trabalha: Baianos, Marinheiros, Erês, e o Povo da Esquerda, englobando Ciganos, Exus, Pombagiras e Exus-Mirins.

Tal qual o entendimento de Verger, o mito da criação na Umbanda é de que Olorum decidiu pela criação do mundo e, nesse sentido:

No início não havia terra. Havia apenas Okun (ou Olokun), o oceano, e a água se estendia sobre todas as coisas. Acima, havia Olorum, o orixá do céu, e Olokun, o orixá do mar, os quais eram contemporâneos. Eles continham (ou possuíam) tudo o que havia. Olorum tinha dois filhos. O primeiro chamava-se Orishalla (o mesmo que Otaballa, também chamado simplesmente de Orixá) e, o mais jovem, Odudua. Olorun convocou oxalá e deu-lhe um pouco de terra, uma galinha com cinco dedos (adje-alesse-manu) 
e disse-lhe: 'Desça (ou vá para a terra) e faça terra sobre Okun'. Oxalá foi. No caminho, encontrou vinho de palma e bebeu até embriagar-se e dormir. Olorum viu isso, chamou Odudua e disse-lhe: 'teu irmão (mais velho) se embriagou pelo caminho. Vá, você, pegue a areia e a galinha com cinco dedos e faça terra sobre Okun'. Odudua foi, tomou a areia, desceu e colocou-a sobre o mar. E colocou a galinha com cinco dedos sobre a areia. (FROBENIUS, 1913, p. 286 apud SILVA, 2015, p. 121). ${ }^{30}$

Segundo tal mito, portanto, havia o Okun e sob a ordem de Olorum, Oxalá foi incumbido de criar a terra, no entanto caiu nos caprichos de Exu, se embriagou e a tarefa coube a seu irmão Odudua. Inconformado com o seu deslize, Oxalá caiu em tristeza profunda e, como forma de tirá-lo de tal estado, Olorum o incumbiu da tarefa de criar os homens.

Logo, há um deus supremo (Olorum) que criou direta ou indiretamente tudo que há, todavia há uma infinidade de outros mitos que diferem deste em aspectos maiores ou menores. De sorte que a Umbanda comporta uma gama muito diversa de mitologias, cultos e liturgias, contudo se encontra uma unidade na diversidade que é capaz de congregar os diversos tipos de Umbanda.

Diante do exposto, dá-se por encerrada a caracterização da Umbanda e procede-se agora ao estudo específico dos Exus, por se tratarem das entidades erroneamente sincretizadas com o demônio cristão e, por isso, constituem no principal alvo de descriminação religiosa.

\subsection{Exus}

Trata-se de entidade associada à fertilidade e a sexualidade, seu culto possui origem africana. Ao se chocar com a civilização cristã de caráter eminentemente maniqueísta foi associado ao mal em oposição ao bom, ao demônio cristão em oposição a deus/jesus, Exu em oposição a Oxalá.

Em sua origem, na África, possui diversos nomes, tais quais: Legbá, Elegbará ou mesmo Exu. É uma entidade mensageira e dinâmica, até mesmo explosiva, devendo ser saudada sempre em primeiro lugar. Nos dizeres de Vagner Gonçalves da Silva, trata-se de um trickster, pois inverte regras e comportamentos, é trapaceiro, brincalhão, esperto, é malandro. Associado à sexualidade e a fertilidade, possui como um dos símbolos de seu culto um falo ereto. ${ }^{31}$

\footnotetext{
30 SILVA, Vagner Gonçalves da. Exu. O guardião da casa do futuro. Rio de Janeiro: Editora Pallas, 2015. p. 92.

31 SILVA, Vagner Gonçalves da. Exu. O guardião da casa do futuro. Rio de Janeiro: Editora Pallas, 2015. p. 2425.
} 
Sobre a associação do culto a Exu e o culto ao falo:

A associação entre o culto ao falus de Exu e o culto do diabo pode ser reveladora sobre esse processo. Os ritos pagãos, assim vistos e condenados pela Igreja Católica na Europa e entre os povos catequizados fora dela, incluíam as cerimônias de fertilidade, nas quais era comum o uso de emblemas associados aos órgãos sexuais masculinos e femininos. A denúncia pelo uso de báculos com ervas alucinógenas esfregados na boca ou na vagina levou muitas mulheres a serem acusadas de feitiçaria ou de cópula com o demônio. Por insondáveis caminhos do imaginário, a representação de um falo (posteriormente associado à vassoura) que as mulheres (acusadas de serem bruxas ou feiticeiras) usavam entre as pernas para supostamente voar pelos campos, propiciando-lhes a fertilidade, encontrou sua correspondência no falo de Exu, que também era usado segundo a mitologia ioruba, para que ele se transportasse ("voasse") para vários lugares instantaneamente. A condenação católica das divindades greco-romanas ou de outras origens associadas a sexualidade e a fertilidade, tidas como "falsos deuses" ou demônios disfarçados, foi reeditada na África com a descoberta deste "Príapo Negro", cultuado com danças tidas como obscenas e repletas de gestos 'extravagantes e diabólicos' (VERGER, 1999, p. 135 apud SILVA, 2015, p. 25). ${ }^{32}$

De forma que a associação entre Exu e demônio cristão precede (e muito) o surgimento das igrejas neopentecostais, sendo muito anterior até mesmo à Reforma.

De fundamental importância é o fato de que no Brasil, o culto a Exu é realizado no chão e na entrada dos terreiros em assentamentos individuais e trancados ou ao ar livre, tal se dá, pois Exu é um trickster e deve ser controlado para que não fuja e espalhe a desordem pelo mundo (BASTIDE, 1978, p. 71 apud SILVA, 2015, p. 84). Portanto, o cadeado exercerá um papel de amplo destaque no culto a Exu, inclusive nos pontos de Umbanda, ${ }^{33}$ ilustrando esse lado de Exu, de uma força que precisa ser controlada.

Quanto ao fato de seu assentamento ser necessariamente próximo à porta dos barracões ou dos terreiros, pode-se afirmar que se deve ao fato do papel de protetor do terreiro e das Giras que ele exerce. Como guardião da porta, cabe a Exu proteger a Gira e a casa da influência de espíritos negativos, atuando verdadeiramente como um protetor.

\footnotetext{
32 SILVA, Vagner Gonçalves da. Exu. O guardião da casa do futuro. Rio de Janeiro: Editora Pallas, 2015. p. 2425.

33 "Portão de ferro, cadeado de madeira, quem manda no cemitério é o Exu Porteira". SILVA, Vagner Gonçalves da. Exu. O guardião da casa do futuro. Rio de Janeiro: Editora Pallas, 2015. p. 24.
} 
Evidencia-se, ainda, a diferenciação quanto à localização dos assentamentos de Exu. Há o assentamento que se realiza dentro do terreiro e o que se localiza na parte de fora, caracterizando, portanto, a existência de dois Exus, a saber: Exu-Compadre e ExuPorteira. Quando se fala do "Exu compadre", se fala de um agregado da família, que em razão da confiança nele depositada e por ele conferida, se dispõe a ajudar nos momentos de maior dificuldade. Ademais, o "Exu de dentro" é o responsável por manter as energias dos trabalhos, da gira e da casa dentro do ambiente. ${ }^{34}$

Já o "Exu do Portão", o "Exu de fora", é aquele que não foi "domesticado" pela confiança nele depositada, de modo que para que realize seus trabalhos e atenda as demandas é necessário que se siga a lógica das trocas, que se faça uma oferenda, um trabalho. No entanto, a relação quase comercial empreendida com o "Exu do Portão", não é o aspecto que salta mais aos olhos, mas, sim, o fato de não haver julgamento de valor por parte de tal entidade. Fugindo totalmente a lógica de oposição maniqueísta do cristianismo, o Exu realiza aquilo que foi lhe pedido, fazendo como única exigência a troca - na Umbanda ainda há a necessidade de se existir "merecimento". Tal fato, o da não realização de julgamentos na ótica de oposição de condutas "boas" em oposição às "más" é de poderosa influência no imaginário popular para que se enxergue o Exu como aquela entidade que causa o mal, a desordem e que prejudica a vida de terceiros como sendo a origem de todo o mal na terra, contribuindo para o paralelismo de sua figura com o "demônio cristão", explorado em larga escala pelas religiões neopentecostais.

Em um dos mitos que envolvem a figura de Exu, ao ser encarregado da criação do mundo, Obàtálà deixou de realizar suas obrigações rituais para Esù - quando da feitura de algum trabalho ou oferenda, deve ser sempre reverenciado, pois é a entidade que rege os caminhos e a comunicação entre os mundos -, Exu (Esù) se viu desrespeitado pelo não cumprimento das obrigações de Obàtálà. Razão pela qual introduzirá o elemento da desordem e usara de todos os seus artifícios para que Obàtálà não consiga realizar a sua tarefa. De sorte que Obàtálà cai em sua armadilha e perde o direito de criar o mundo. Cabendo a tarefa à Odùa que conta com a simpatia de Exu por ter dado oferendas a ele.

No mito em questão, Exu é o agente da desordem. Atua visando introduzir a mudança e quebrar a ordem quando não é agradado, evidenciando ainda mais seu papel de trickster. Todavia, quando se realiza os rituais que lhe são devidos, Exu também agirá como transformador introduzindo elementos de mudança. Portanto, Exu transita entre os mundos da Ordem e da Desordem, da mudança para uma direção ou outra, a depender do respeito ou não a seus rituais.

34 SILVA, Vagner Gonçalves da. Exu. O guardião da casa do futuro. Rio de Janeiro: Editora Pallas, 2015. p. 87. 
Volta-se, agora, para as figuras "brasileiras" do Exu, que exercem fundamental importância no imaginário popular e no quadro da intolerância religiosa.

Um dos principais Exus "brasileiros" surgiu na Umbanda e se chama Zé Pilintra.

Zé Pilintra é uma entidade que se manifesta na linha de Exu, é a figura caricata do boêmio carioca do início do século XX, seria uma espécie de malandro divino. Seus trajes tradicionais são o paletó, calça e sapatos brancos em amplo contraste com a gravata e o lenço vermelhos, simbolizando a ordem e a desordem. Seu modo de vestir, sempre elegantemente trajado e com vestes formais, seria uma forma de ludibriar as pessoas quanto a sua posição de marginal social e chamar atenção para si como excluído sem lugar próprio na estrutura da sociedade brasileira. ${ }^{35}$

Evidencia-se, portanto, o caráter típico do malandro carioca do século XX, aquele que por ser excluído e marginalizado da sociedade se vê obrigado a praticar pequenos golpes e contravenções a fim de se obter o sustento do dia a dia, atua verdadeiramente como trickster, e faz uso de sua vestimenta elegante para tentar esconder o seu caráter de párea social.

\subsection{Pombagiras}

As pombagiras habitam o imaginário popular brasileiro há muito e figuram como um dos principais alvos da discriminação e intolerância às religiões afro-brasileiras.

No entanto, pouco se sabe efetivamente sobre o que seriam elas. As Pombagiras são entidades femininas da linha de Exu e, portanto, possuem todas as características dessa linha de trabalho, a figura de trickster, o trânsito entre os mundos da ordem e da desordem, do material e do espiritual e, como não poderia deixar de ser, foge ao maniqueísmo cristão.

Uma vez mais, far-se-á uso da maestral descrição de Vagner Gonçalves da Silva, que as caracteriza como:

[Pombagira] Esta seria um trickster feminino que desafia a ordem patriarcal da sociedade brasileira por meio da não aceitação da mulher aos papéis domésticos tradicionais de esposa e mãe. Embora ela possa ser vista como mãe, é como 'mulher da rua', e não 'da casa', que a pomba-gira assume o estereótipo da prostituta. Nesse sentido, seu poder decorre do domínio que manifesta sobre seu corpo e sua vontade, ainda que isso lhe custe uma reputação social estigmatizada. Ela se utiliza da diferença biológica (pênis e vagina),

\footnotetext{
35 SILVA, Vagner Gonçalves da. Exu. O guardião da casa do futuro. Rio de Janeiro: Editora Pallas, 2015. p. 157. 
associada ao sexo biológico (macho e fêmea) e aos papéis de gênero (masculino e feminino), para questionar por meio da jocosidade e da licenciosidade o poder social que instaura relações de dominação a partir destes marcadores sociais da diferença. ${ }^{36}$

Continuando com a caracterização das pombagiras como entidades femininas desafiadoras da ordem patriarcal da sociedade, Vânia Z. Cardoso coloca sob o holofote a identificação de tais entidades com a marginalidade social na forma da prostituição, evidenciando, ainda, seu caráter de sexualidade abundante e amplamente manifestada.

Da Silva encerra a questão da ampla sexualização das entidades de religiões afro-brasileiras, principalmente as de Esquerda, quando diz:

De qualquer modo, os Exus, segundo a iconografia das imagens umbandistas, são representações de homens de corpos viris, seminus, de cor de pele 'marrom' e em muitos casos de fenótipo negro-africano e feição ameaçadora. Trata-se, sem dúvida, de representações associadas ao corpo africano escravizado de seus descendentes mestiços, vistos como seres de uma sexualidade exacerbada. O mesmo se pode afirmar sobre a Pombagira, que representaria principalmente mulheres de comportamento moral ou sexual tido como reprovável. Quando incorporadas manifestam gestos expansivos e eróticos, utilizam 'palavrões' ou expressões jocosas e de duplo sentido, consomem bebida alcoólica e fumam. Este imaginário, em muitos casos, reproduz, no plano mítico, o poder de sedução atribuído às mulheres negras e mulatas, cuja sexualidade e erotização foram apanágios da visão deturpada impingida pela sociedade brasileira às mulheres africanas e, posteriormente, mestiças no regime escravocrata e no contexto urbano pósabolição. Entretanto, quero enfatizar que, para além destes estereótipos, a livre expressão destes corpos diz respeito também a possibilidade de oposição a dominação pela aceitação inicial dos estereótipos, para em seguida usá-los a fim de criticar a ordem social que os gerou. A mulher feita de prostituta 'aceita' a prostituição para depois rir e escandalizar a sociedade que a gerou. ${ }^{37}$

\footnotetext{
36 SILVA, Vagner Gonçalves da. Exu. O guardião da casa do futuro. Rio de Janeiro: Editora Pallas, 2015. p. 24.

37 SILVA, Vagner Gonçalves da. Exu. O guardião da casa do futuro. Rio de Janeiro: Editora Pallas, 2015. p. 8081.
} 
O que se vê, portanto, é que nem mesmo o plano da representação religiosa se viu imune aos efeitos do regime de escravidão. Os Orixás cultuados pelas religiões afro-brasileiras são erotizados pelo imaginário popular.

As Pombagiras são as entidades que mais sofrem com os estereótipos e com a erotização exacerbada do corpo da mulher negra. A pombagira é a mulher negra da sociedade patriarcal e machista em que se vive atualmente, de tal forma que é a mulher negra que sofre diariamente o assédio e a erotização incessante e exacerbada de seu corpo, é a mulher negra que é vítima do machismo, que sofre violências físicas e psicológicas por simplesmente possuir o domínio de seu corpo e vivenciar sua sexualidade, é a mulher que na sociedade capitalista - por natureza machista e patriarcal - não é dada uma existência digna. Todavia, o que de fato caracteriza as pombagiras é o seu caráter de irresignação, as pombagiras não se calam ante o quadro assustador e opressivo que a sociedade impõe a mulher, se revoltam e lutam contra o machismo e o patriarcado por meio da "não aceitação da mulher aos papéis domésticos tradicionais de esposa e mãe" e, principalmente, pelo "domínio que manifesta sobre seu corpo e sua vontade, ainda que isso lhe custe uma reputação social estigmatizada", estigmas que não passaram incólume ante sua característica transformadora, pois irá, posteriormente, revertê-los.

É, devido, a sua atitude revolucionária e de subversão da ordem machista e patriarcal da sociedade que as pombagiras são demonizadas e são os maiores alvos da intolerância religiosa. Como se explicará melhor em momento oportuno, ao se demonizar e atacar as pombagiras, em verdade o estão fazendo com a mulher que luta para ser verdadeiramente livre e não se cala ante a opressão que a sociedade lhe impõe. As pombagiras são mais uma das inúmeras vítimas que o machismo faz diariamente.

\section{Intolerância religiosa do Estado}

Chega-se ao momento do desenvolvimento do presente estudo em que para se compreender o fenômeno da intolerância religiosa e seu desenvolvimento, até a chegada aos níveis alarmantes da atualidade, deve-se analisar a legislação pertinente a tal tema que vigorou em território nacional.

Inicia-se com o texto da Constituição do Império de 1824. A começar por seu prólogo, o texto legal é repleto de referências à religiosidade católica e o primeiro título do documento versa sobre o Império brasileiro, seu território, seu governo, sua dinastia e sua religião. Como pode se verificar, juntamente com os elementos fundantes do Estado brasileiro - território e governo - elenca-se a religião oficial do Império.

Reza o art. $5^{\circ}$ da Constituição Imperial de 1824 que:

Art. 5. A Religião Catholica Apostolica Romana continuará a ser a Religião do Imperio. Todas as outras Religiões serão permitidas com seu culto domestico, ou particular em casas 
para isso destinadas, sem fórma alguma exterior do Templo.

Disponível em: <http://www.planalto.gov.br/ccivil_03/

Constituicao/Constituicao24.htm>.

Não há nenhuma dúvida quanto a interpretação do texto legal, a religião oficial do Império brasileiro era a Católica Apostólica Romana. Contudo, analisando-se brevemente $o$ artigo transcrito, pode-se chegar a falsa conclusão de que apesar de o Estado brasileiro não ser laico, haveria liberdade de crença e culto.

Ledo engano, ora, permite-se o culto doméstico, na residência dos praticantes ou em templos para isso erguidos, sem que haja qualquer forma de sinalização. Ora, tal constituição teve o seu período de vigência durante os terríveis anos da escravidão. De modo que os participantes das religiões afro-brasileiras eram em sua totalidade escravos, de sorte que não possuíam residências próprias para realizarem os seus cultos, tampouco havia templos com tais finalidades. Sendo obrigados por essa e tantas outras circunstâncias a esconder suas crenças dentro da fé católica, originando o fenômeno sincretista.

Vê-se que o Estado outorga para si a competência de determinar como e onde se praticarão os credos que não são o oficial.

Com o advento da república em 1889, promulga-se uma nova constituição somente no ano de 1891. Com a nova norma, surgem e se consagram os ideais republicanos de governo e, portanto, há a tão esperada separação entre Estado e Religião. Preconiza o seu art. 11:

Art. 11 - É vedado aos Estados, como à União:

$2^{\circ}$ ) estabelecer, subvencionar ou embaraçar o exercício de cultos religiosos;

Disponível em: <http://www.planalto.gov.br/ccivil_03/ Constituicao/Constituicao91.htm>.

Portanto, a letra da lei assegura a liberdade de culto e de crença na medida em que coloca como proibidas as práticas estatais que estabeleçam cultos ou que os constrinjam. Todavia, não é uma afirmação de caráter positivo, o Estado não anuncia nos moldes do "poder", não afirma indubitavelmente que é livre toda a manifestação de crença e seus cultos, meramente proíbe seu constrangimento. Tal enunciação não foi suficiente, de modo que se adiciona em 1926, por meio de emenda constitucional, o art. 72, que diz:

Art. 72 - A Constituição assegura a brasileiros e a estrangeiros residentes no paiz a inviolabilidade dos direitos concernentes á liberdade, á segurança individual e á propriedade, nos termos seguintes:

$\S 3^{\circ}$ Todos os individuos e confissões religiosas podem exercer publica e livremente o seu culto, associando-se para esse fim e adquirindo bens, observadas as disposições do direito commum. (Redação dada pela Emenda 
Constitucional de 3 de setembro de 1926). Disponível em: <http://www.planalto.gov.br/ccivil_03/Constituicao/ Constituicao91.htm>.

De modo que a partir do surgimento de tal emenda há uma afirmação positiva por parte do Estado, do diploma constitucional de que todos os cultos são permitidos e a liberdade a eles é assegurada.

A constituição mantém essa liberdade aparente de culto, contudo deixa transparecer de modo mais claro que tal liberdade é inverídica e seletiva, ao dizer que:

Art. 113 - A Constituição assegura a brasileiros e a estrangeiros residentes no País a inviolabilidade dos direitos concernentes à liberdade, à subsistência, à segurança individual e à propriedade, nos termos seguintes:

$5^{\circ}$ ) É inviolável a liberdade de consciência e de crença e garantido o livre exercício dos cultos religiosos, desde que não contravenham à ordem pública e aos bons costume. As associações religiosas adquirem personalidade jurídica nos termos da lei civil.

Disponível em: <http://www.planalto.gov.br/ccivil_03/ Constituicao/Constituicao34.htm>.

Quanto a liberdade positiva, não há mudança com relação ao texto legal que a precedeu, a Constituição de 1934 continua a permitir a livre manifestação religiosa. Todavia, acrescenta uma característica ao culto religioso que deve ser seguida para que o seu "livre exercício" seja permitido, deve-se respeitar, impreterivelmente à ordem pública e os bons costumes.

Ao condicionar o livre exercício religioso e a liberdade de crença a conceitos jurídicos tão abertos, o legislador constituinte de 1934 permitiu que a intolerância e a perseguição religiosa se justificasse e se eivasse de legalidade. Senão vejamos, o que são os bons costumes? A ordem pública? Nada mais são do que conceitos abertos que expressam as ideias dominantes da sociedade brasileira do início do século XX, sabe-se que as ideias dominantes sempre foram e o serão para a eternidade as ideias da classe dominante.

Ora, trata-se do início do século XX, aboliu-se o regime da escravidão recentemente e se encontra no início da chamada Era Vargas, que após a eclosão da Revolução Constitucionalista de 1932 se viu obrigado a promulgar tal Constituição. O quadro descrito é o de uma sociedade eminentemente racista, classista e machista. Indaga-se, portanto, se não era no mínimo óbvio que se consideraria uma religião de origem escrava, africana, na qual as figuras femininas são de imponência e papéis até revolucionários e que possui na música, nos atabaques e agogôs, um de seus elementos principais, não seria atentatória a "ordem pública" e aos "bons costumes". 
As justificativas encontradas no Direito e na Lei para a perseguição às religiões afro-brasileiras são encontradas, também, no universo infraconstitucional. $\mathrm{O}$ Decreto-Lei n. 3.688/1941, preconiza em seu art. 42 o que se segue:

Art. 42. Perturbar alguem o trabalho ou o sossego alheios:

I - com gritaria ou algazarra;

$[\ldots]$

III - abusando de instrumentos sonoros ou sinais acústicos;"

Disponível em: <http://www.planalto.gov.br/ccivil_03/ decreto-lei/Del3688.htm>.

Tanto na Umbanda quanto no Candomblé, a musicalidade exerce um papel de suma importância durante o culto. Para que se crie no ambiente as vibrações necessárias para a incorporação mediúnica, entoam-se músicas - os chamados pontos e os instrumentos de percussão são tocados em ritmos certos e determinados, variando conforme a entidade ou linha de trabalho. De modo que a contravenção estabelecida pelo art. 42 do Decreto-Lei n. 3.688/1941, que possuía como pena de quinze dias a três meses de prisão, além da multa, funcionou como embasamento jurídico para as invasões e destruições de terreiros durante o período da Era Vargas.

Portanto, a ideia de liberdade religiosa perpassada pelo dispositivo Constitucional se mostra amplamente inverídica e irreal ao se condicionar a sua existência aos conceitos abertos de "ordem pública" e "bons costumes". Ademais, o Decreto-Lei n. 3.688, de 1941, ao criminalizar as chamadas "gritarias ou algazarras" e o "abuso de instrumentos sonoros", forneceu o embasamento legal para a perseguição religiosa durante o Governo Vargas.

Pode-se concluir que no período ora descrito a intolerância religiosa se inseria na ótica do Estado e se manifestava por meio de seus órgãos e agentes. Destaca-se para a figura do Delegado de Polícia baiano que obteve fama reprimindo as manifestações da cultura e religiosidade afro-brasileiras, trata-se do delegado Pedrito gordo.

Descreve Jorge Amado em sua grande obra Tenda dos Milagres:

Na cidade, o delegado Pedrito Gordo soltara a malta do terror com carta branca: invadir terreiros, destruir pejis, surrar babalaôs e pais de santo, prender feitas e iaôs, iá-quequerês e ialorixás. 'Vou limpar a Bahia dessa imundície!'. Deu ordens estritas aos soldados da polícia, organizou a escolta de bandidos, partiu para a guerra santa. (AMADO, 2008, p. 207).

Continua em sua impressionante descrição do fenômeno da perseguição as religiões afro-brasileiras: 
Era preciso mostrar serviço com urgência, fazer qualquer coisa capaz de restaurar o prestígio abalado por Enéas Pombo e seu revólver. Algo espetacular, de preferência. O quê?

- E se a gente saísse por aí e acabasse com uns Candomblés?propôs Candinho Faroleiro.

- Você deu no sete. O doutor Pedrito vai gostar - apoiou Mirandolino. (AMADO, 2008, p. 209)

No trecho em destaque, nota-se que os subalternos de Pedrito Gordo, movidos pela necessidade constante de agradar o chefe para não perder os empregos - e com eles a vida - se dirigem para a destruição de terreiros e prisão do "povo de santo". Ação que era embasada pela Constituição Federal vigente à época e pelo decreto supracitado, contudo o que motivava o delegado a perseguir os terreiros senão o mais profundo ódio racial, de classe e de gênero?

No gabinete de Pedrito Gordo, numa pequena estante, alinhavam-se livros e opúsculos, alguns do tempo de faculdade, outros lidos depois da formatura, marcados a lápis vermelho, vários de publicação recente. As três escolas penais: Clássica, antropológica e crítica, de Antônio Moniz Sodré de Aragão, adepto da escola antropológica italiana, Degenerados e criminosos, de Manuel Bernardo Calmon Du Pin e Almeida, Craniometria comparada das espécies humanas da Bahia sob o ponto de vista evolucionista médico-legal, de João Batista de Sá Oliveira; Germes do crime, de Aurelino Leal. Nesses livros, e nos trabalhos de Nina Rodrigues e de Oscar Freire, o estudante Pedrito Gordo, nas sobras do tempo dedicado às pensões de mulheres, aprendera que negros e mestiços possuem natural tendência ao crime, agravada pelas práticas bárbaras do candomblé e das rodas de samba, de capoeira, escolas da criminalidade a aperfeiçoar quem já nascera assassino, ladrão, canalha. Branco, baiano, vacilando entre o loiro e o sarará, o delegado considerava a exibição de tais costumes monstruoso acinte entre às famílias, achincalhe à cultura, à latinidade que tanto se orgulhavam intelectuais, políticos, comerciantes, fazendeiros, a elite. [...] Quando certos demagogos, em busca de popularidade entre a ralé, a plebe, o zé povinho, punham-se a discutir a repressão aos costumes populares e os métodos violentos usados pela polícia para silenciar atabaques, ganzás, berimbaus, agogôs e caxixis, para impedir a dança das feitas e dos capoeiras, o delegado auxiliar Pedrito Gordo exibia a cultura antropológica e jurídica de sua estante: 'São os mestres que afirmam a periculosidade da negralhada, é a ciência que proclama guerra às suas práticas antissociais, não sou eu'. Num 
gesto de humildade completava: 'Apenas trato de extirpar o mal pela raiz, evitando que ele se propague. No dia em que tivermos terminado com toda essa porcaria, o índice de criminalidade em Salvador vai diminuir enormemente e por fim poderemos dizer que nossa terra é civilizada'. (AMADO, 2008, p. 210).

Pedrito Gordo é, portanto, cidadão de classe média, que frequentou a faculdade e ao sair encontrou no Estado e no seu emprego público um modo de exercitar suas crenças e uma forma de distribuir seu ódio racial. No ambiente acadêmico teve contato com teorias do determinismo jurídico que não só justificaram os seus preconceitos enraizados pela sociedade capitalista - que é corolário do preconceito, por definição, uma vez que para se justificar ante a sua psique o ser humano necessita de diferenciação para justificar a exclusão e exploração econômica - como o aumentaram através das ditas evidências e provas científicas nas quais se embasaram. Ao assumir a posição de Delegado de Polícia, adentra o rol de agentes do estado e, como tal, sua ação é limitada pelas balizas da legalidade, como a obra de Jorge Amado se passa em Salvador em meados da década de 1940, afirma-se que encontra na Constituição de 1934 e no Decreto-Lei já citado os fundamentos legais para as suas ações de ódio de raça e gênero.

De modo que, a despeito de suas características individuais, a repressão não se dá pelo fato determinante de ser ele o chefe da polícia, mas pelo fato de que a própria estrutura jurídica do Estado proporcionava e justificava a ação do seu aparato repressor contra as religiões afro-brasileiras. Antes de uma atitude fruto de condutas esporádicas e individuais de Pedrito Gordo, a intolerância religiosa do período Vargas era fruto da movimentação do aparato estatal, incluía-se na lógica legal/ilegal do Direito, na qual as religiões afro-brasileiras se encontravam no último polo.

Ainda durante o período de Governo de Getúlio Vargas, em 1937 há a promulgação de um novo texto constitucional, a constituição do chamado Estado Novo, a quarta do Brasil e que não inova na matéria de liberdade religiosa, mantendo os dispositivos que passam a falsa ideia de liberdade que já existiam.

Com o fim do Estado Novo e a deposição de Getúlio Vargas no final do ano de 1945, convoca-se uma nova assembleia constituinte com a missão de elaborar uma nova Carta Magna. Com o fim do regime ditatorial, concede-se liberdade de organização para os partidos que eram perseguidos durante o regime de Vargas, dentre eles o Partido Comunista Brasileiro, que desempenhará papel fundamental na elaboração da nova constituição. 
O Partido Comunista Brasileiro elege quatorze Deputados e um Senador para figurar em tal assembleia, a saber: ${ }^{38}$ Gregório Bezerra, José Maria Crispim, Maurício Grabois, Claudino José da Silva, Joaquim Batista Neto, Osvaldo Pacheco, Abílio Fernandes, Alcides Sabença, Agostinho Dias de Oliveira, João Amazonas, Milton Caires de Brito, Alcedo Coutinho, Jorge Amado e Carlos Marighella. Sendo o Senador, o lendário Cavaleiro da Esperança, Luis Carlos Prestes, que fora anistiado no final do regime ditatorial do Estado Novo.

Em meio a uma acalorada discussão no plenário da Assembleia Constituinte, Carlos Marighella proferiu o seguinte discurso:

Nós, comunistas, sabemos respeitar as religiões; somos pela liberdade completa de consciência e não desejamos, de forma alguma, que essa liberdade seja utilizada pelos dominadores, pelos fascistas, pelos reacionários, pelos senhores feudais para acorrentar o nosso povo, miseravelmente, como o têm feito.

Não combatemos religiões, porque não seria útil, proveitoso, nem mesmo científico, visto que a religião só desaparecerá quando desaparecerem os antagonismos de classe. É necessário compreender que, hoje, todo o povo sofre sem que seus dominadores se lembrem de procurar ver se os que estão sendo explorados são católicos, positivistas, teosofistas, ateus, ou pertencem a qualquer outro credo religioso. O patrão, capitalista explorador, não paga melhor salário a seus operários, porque se trata de um católico se a religião desse patrão é a católica. O sistema de exploração é o mesmo. A única divisão que se pode fazer no seio da sociedade é realmente entre os explorados e os exploradores.

Daí, Senhores Constituintes, a posição do Partido Comunista em querer lutar, com todas as forças da democracia, como Partido democrata que é, para garantir, no Brasil, a liberdade de consciência, respeitando-se todos os credos, fazendo que se não estabeleça privilégio de um credo sobre os demais, ou não se recorra a essa situação, no sentido de impedir a liberdade democrática e acorrentar mais ainda a nossa gente. $^{39}$

Nota-se que o PCB na figura de Carlos Marighella - apesar de considerar a religião somente como "ópio do povo" que chegará ao fim juntamente com as classes

38 Disponível em: $<$ http://grabois.org.br/portal/cdm/revista.int.php?id_sessao=50\&id_publicacao=147\&id_ indice $=886>$. Acesso em: 12 out. 2015.

39 Disponível em: <http://pcb.org.br/portal/index.php?option=com_content\&view=article\&id=6314:liberda de-de-culto-uma-divida-do-brasil-para-com-o-pcb\&catid=56:memoria>. Acesso em: 12 out. 2015. 
sociais, - luta com afinco pela liberdade de culto e de crença, de sorte que o escritor baiano Jorge Amado encaminhará ao plenário a proposta que assegura a liberdade de culto e de crença.

Reza o art. 141 da Constituição brasileira de 1946

Art. 141 - A Constituição assegura aos brasileiros e aos estrangeiros residentes no País a inviolabilidade dos direitos concernentes à vida, à liberdade, a segurança individual e à propriedade, nos termos seguintes:

$[\ldots]$

$\S 7^{\circ}$ - É inviolável a liberdade de consciência e de crença e assegurado o livre exercício dos cultos religiosos, salvo o dos que contrariem a ordem pública ou os bons costumes. As associações religiosas adquirirão personalidade jurídica na forma da lei civil. ${ }^{40}$

Analisando-se o contexto histórico em que ocorreu a aprovação da proposta de Jorge Amado, considerar-se-á que foi antes de tudo uma vitória, uma vez que havia grande pressão para que se suprimisse a liberdade religiosa e separou-se pela primeira vez liberdade de culto, de crença e de consciência. Contudo, foi uma vitória apenas parcial, uma vez que ainda persistia a condição de que para haver a liberdade de culto deveria se respeitar os conceitos abertos de "ordem pública" e "bons costumes", abrindo-se ampla margem para a perseguição aos cultos afro-brasileiros.

O surgimento de um novo regime ditatorial no Brasil com o golpe militar de $1^{\circ}$ de abril de 1964, faz surgir a necessidade de um novo texto constitucional, promulgado em 1967. A constituição de 1967 não inova na matéria de liberdade religiosa e mantém a condição de respeito à "ordem pública" e aos "bons costumes". ${ }^{41}$

Com a queda da Ditadura Civil-Militar e o consequente processo de redemocratização, surge a Constituição de 1988, consagrando os princípios do chamado Estado Democrático de Direito e suas liberdades inerentes, assegurando, dessa forma, a plena a liberdade de consciência, culto e crença, como se vê:

40 Disponível em: < http://www.planalto.gov.br/ccivil_03/Constituicao/Constituicao46.htm>. Acesso em: 12 out. 2015.

41 Art. 150 - A Constituição assegura aos brasileiros e aos estrangeiros residentes no Pais a inviolabilidade dos direitos concernentes à vida, à liberdade, à segurança e à propriedade, nos termos seguintes: [...] $\S 5^{\circ}-$ É plena a liberdade de consciência e fica assegurado aos crentes o exercício dos cultos religiosos, que não contrariem a ordem pública e os bons costumes.

Art. $9^{\circ}$ - A União, aos Estados, ao Distrito Federal e aos Municípios é vedado: [...] II - estabelecer cultos religiosos ou igrejas; subvencioná-los; embaraçar-lhes o exercício; ou manter com eles ou seus representantes relações de dependência ou aliança, ressalvada a colaboração de Interesse público, notadamente nos setores educacional, assistencial e hospitalar. Disponível em: <http://www.planalto.gov.br/ccivil_03/Constituicao/ Constituicao67.htm>. Acesso em: 12 out. 2015. 
Art. $5^{\circ}$ Todos são iguais perante a lei, sem distinção de qualquer natureza, garantindo-se aos brasileiros e aos estrangeiros residentes no País a inviolabilidade do direito à vida, à liberdade, à igualdade, à segurança e à propriedade, nos termos seguintes:

$[\ldots]$

VI - é inviolável a liberdade de consciência e de crença, sendo assegurado o livre exercício dos cultos religiosos e garantida, na forma da lei, a proteção aos locais de culto e a suas liturgias; ${ }^{42}$

Analisando-se o texto constitucional, pode-se concluir com facilidade de que a lei assegura a plena liberdade de culto, de consciência e de crença. Não há nenhuma vinculação da liberdade de culto aos conceitos abertos de "ordem pública" e "bons costumes", que durante décadas justificaram as ações repressivas do aparato estatal. Houve considerável avanço, uma vez que o Estado não só assegura a liberdade, mas garante a proteção aos locais de culto e suas liturgias, o aparelho que antes reprimia agora deve proteger. No entanto, é patente que ainda há intolerância e perseguição às religiões afro-brasileiras. $\mathrm{O}$ que houve foi a mudança de agente da repressão, passa-se da ótica do agente estatal, público, para a ação do agente privado. Tal questão será desenvolvida no capítulo que se segue.

\section{Intolerância religiosa da Sociedade}

Para que se entenda corretamente o processo de transferência da perseguição e da intolerância religiosa aos cultos afro-brasileiros, de uma ótica do Estado para a ótica do particular, da sociedade, é necessário que se estude a chegada e o desenvolvimento das chamadas religiões pentecostais e neopentecostais em território pátrio.

No ano de 1910, chega a território Brasileiro a primeira igreja pentecostal, a Congregação Cristã do Brasil, trazida pelo imigrante italiano Luigi Francescon, um dos fundadores da Igreja Presbiteriana Italiana em Chicago. De sorte que a primeira igreja pentecostal brasileira sofreu grande influência do culto protestado nos Estados Unidos.

Já em 1911, surge uma nova denominação pentecostal, trazida pela Missão Pentecostal Sueca, a Igreja Evangélica Assembleia de Deus. Relata-se que os missionários Gunnar Vingren e Daniel Berg, que eram batistas suecos radicados nos Estados Unidos, receberam uma "profecia" a qual lhes incumbia a missão de levar as palavras do evangelho

42 Disponível em: $<$ http://www.planalto.gov.br/ccivil_03/Constituicao/Constituicao.htm>. Acesso em: 12 out. 2015. 
a um lugar chamado Pará. ${ }^{43}$ Portanto, o início do pentecostalismo em território brasileiro se dá no início do século XX, portanto a intolerância religiosa ainda era uma prática de Estado, com a fundação da Congregação Cristã do Brasil (1910) e com a Igreja Evangélica Assembleia de Deus (1911).

Os anos 1950 são marcados por uma profunda e ampla expansão e diversificação do movimento pentecostal brasileiro, tal se dá pela chegada em 1951 do missionário norte-americano Harold Williams em nome da Igreja do Evangelho Quadrangular, que já existia havia décadas nos Estados Unidos, de modo que foi a primeira denominação pentecostal de origem inteiramente estadunidense a se instalar no Brasil. ${ }^{44}$ Uma das principais características do culto praticado na Igreja do Evangelho Quadrangular foi o fato de que transformou a "cura" um sua atividade principal, na força motriz de seu processo de expansão e conquista de fiéis, liderando a chamada "Cruzada Nacional de Evangelização", imprimindo uma forte prática evangelista e missionária, na qual a cura e os milagres eram o seu principal chamariz. Com o crescimento da Igreja do Quadrangular, novas lideranças se desenvolveram, ocasionando uma série de cismas, levando a fundação de novas denominações, tais quais: O Brasil Para Cristo (1956), Deus é Amor (1962), Casa de Bênção (1964), entre outras.

Os anos 1980 presenciaram um grande crescimento dos segmentos pentecostais e neopentecostais, surgidas dos mais diversos cismas e choques de lideranças, popularizando-se a figura do "crente" que prega em praça pública como símbolo da prática evangelista ousada e ofensiva de tais igrejas. Portanto, há uma coincidência cronológica entre a saída da perseguição religiosa da esfera do estado (Constituição Federal de 1988) e o crescimento experimentado pelas Igrejas Evangélicas na década de 1980.

O crescimento de tais Igrejas se deu por meio da criação de verdadeiras confrarias, nas quais os "irmãos de fé" se ajudam mutuamente e excluem aqueles que não comungam com suas crenças, e, principalmente, pela mudança de centralidade da ótica surgida pela Reforma. Ora, se nas primeiras Igrejas surgidas com a Reforma Protestante a centralidade do culto se dava no sermão, na pregação e a livre interpretação do texto sagrado desempenhava um papel fundamental, nas Igrejas Neopentecostais, o sermão é de pouca relevância no culto, os seus adeptos pouco conhecem do texto bíblico e o momento apoteótico se dá com a "cura", com o exorcismo, com a prática de supostos milagres.

Portanto, o clímax do culto das Igrejas Neopentecostais, em especial da Igreja Universal do Reino de Deus é a "cura", diz a lógica que a "cura" pressupõe uma doença, um mal que deve ser extirpado com força máxima, no entanto, o que seria esse

\footnotetext{
43 ALMEIDA, Ronaldo de. A Igreja Universal e seus demônios. Um estudo etnográfico. São Paulo: Editora Terceiro Nome, 2009.

$44 \quad$ Id. Ibid. p. 31.
} 
mal? A resposta é simples, o mal seria o demônio que se faz presente na terra por meio dos cultos afro-brasileiros, manifestando-se, sempre, sem exceção, como Exu.

Far-se-á, neste momento, uma análise do culto da Igreja Universal do Reino de Deus, tendo como foco aqueles dedicados ao exorcismo e suas estruturas.

Não por mero acaso os cultos dedicados ao exorcismo e a libertação - o chamado descarrego - são realizados às sextas-feiras, dias associados comumente aos cultos de Candomblé e Umbanda. ${ }^{45}$ A convocação para esse tipo de culto é feita por meio de panfletos, os quais são cheios de testemunhos de fiéis que possuíam passados pecaminosos e eram dominados por alguma espécie de demônio e foram libertos por tais práticas. Além de sua conversão e libertação, há outro fator que liga os personagens dos folhetos, de alguma forma se relacionaram com as relações afro-brasileiras, em uma clara associação delas com todo mal e negatividade presentes no mundo. Nesse sentido, diz Ronaldo de Almeida:

O conteúdo das cartas é bem particular: o programa visa à oração pelos ouvintes e à explicação de como são realizados os diversos feitiços do Candomblé, da macumba, da Umbanda, do vodu etc., de que eles confessam terem sido vítimas.

O pastor Mauro com certeza é uma pessoa bem habilitada para falar desse assunto. Ele, assim como parte dos fiéis da Igreja Universal, é egresso de uma dessas religiões. Em seu caso, a mudança ocorreu com maior radicalismo. Antes de se tornar pastor, ele era pai-de-santo no Candomblé, sendo Mauro de Ogum ${ }^{46}$ o seu antigo nome-de-fé.

Os livros, a Folha Universal, os programas no rádio e na televisão, assim como os inúmeros testemunhos públicos nos templos, alardeiam reiteradamente as incontestáveis conversões de umbandistas, macumbeiros, kardecistas, candomblezeiros a Universal. Quando mais "pecaminoso" é o passado dos novos fiéis com essas religiões, maior é o destaque de suas histórias de vida. ${ }^{47}$

45 ALMEIDA, Ronaldo de. A Igreja Universal e seus demônios. Um estudo etnográfico. São Paulo: Editora Terceiro Nome, 2009. p. 67.

46 Importantes apontamentos existem no sentido de que a conversão das religiões afro-brasileiras para as neopentecostais, e o contrário, seriam facilitadas pelo fato de que ambas possuem estrutura piramidal. Nas religiões afro-brasileiras seria: FIEL - EXU - ORIXÁS e ENTIDADES e nas Neopentecostais FIEL PASTOR - DEUS (JESUS), sendo o elemento do meio o elemento de ligação, de comunicação entre os dois mundos, do terreno e do sagrado.

47 Id. Ibid. p. 68-69. 
Cria-se, portanto, um nexo entre a saída das religiões mediúnicas e a conversão à Igreja Universal, com o progresso material e espiritual do indivíduo, como se suas antigas práticas religiosas fossem a causa de suas desgraças e fonte de todo mal.

Durante o culto há incontáveis referências às práticas dos terreiros e sua associação direta com os aspectos negativos da vida do fiel, se há algo que não funciona na vida do indivíduo a causa disso certamente se origina em um terreiro, seja ele de Candomblé ou Umbanda.

No entanto, o aspecto que mais salta aos olhos em tais cultos é o dos demônios que se manifestam. De tantas outras religiões que não compactuam com as crenças, com a doutrina e com a liturgia da Igreja Universal do Reino de Deus, manifestamse, somente, os espíritos relacionados aos cultos de afro-brasileiros, mais especificamente os demônios que atravancam a vida dos fiéis e são a origem de todo mal na face da terra são necessariamente: Exus, Pombagiras ou Exus-mirins. Ora, a prática do budismo vai contra os preceitos da Universal, contudo jamais se viu um o espírito de Sidarta Gautama se manifestando em um culto da Universal. As razões específicas da predileção pelos cultos afro-brasileiros serão explicitadas à guisa de conclusão deste trabalho.

Não causa espanto, em um cenário de demonização das práticas dos terreiros, que tenha havido um aumento exponencial da violência praticada contra as religiões afro-brasileiras, ainda com a alarmante criação do grupo de caráter paramilitar “Gladiadores do Altar", ${ }^{48}$ cujas finalidades ainda não foram esclarecidas. Segundo dados estatísticos da Secretária Para Promoção da Igualdade Racial, as denúncias de intolerância religiosa subiram $600 \%$ no ano de $2012 .{ }^{49}$

$\mathrm{O}$ ano de 2015 mostra que houve um recrudescimento do cenário e um aumento brutal da perseguição às religiões afro-brasileiras, como demonstrado pelas manchetes que se seguem: "Jovem de 14 anos praticante de candomblé denuncia ter sido agredida por intolerância religiosa em Curitiba", ${ }^{50}$ "Quase 1 mil casos de intolerância religiosa foram registrados no Rio de Janeiro em dois anos", 51 "Menina vítima de pedrada após sair de festa do Candomblé é alvo de ofensas ao ir fazer exame de corpo de delito", 52

48 Igreja Universal cria grupo conhecido como Gladiadores do Altar, o seu 'Exército fundamentalista'. Disponível em: <http://www.brasilpost.com.br/2015/03/03/gladiador-do-altar-universal_n_6790706.html>. Acesso em: 14 out. 2015.

49 Disponível em: <http://memoria.ebc.com.br/agenciabrasil/noticia/2013-01-21/denuncia-de-intoleranciareligiosa-cresce-mais-de-600-em-2012>. Acesso em: 14 out. 2015.

50 Disponível em: <http://www.geledes.org.br/jovem-de-14-anos-praticante-de-candomble-denuncia-ter-sidoagredida-por-intolerancia-religiosa-em-curitiba/\#gs.ryEfY=0>. Acesso em: 14 out. 2015.

51 Disponível em: < http://www.geledes.org.br/quase-1-mil-casos-de-intolerancia-religiosa-foram-registradosno-rio-de-janeiro-em-dois-anos/\#gs.ZFjYTbs>. Acesso em: 14 out. 2015.

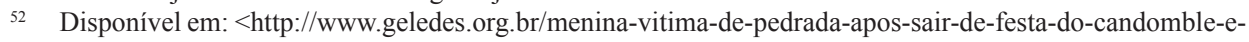
alvo-de-ofensas-ao-ir-fazer-exame-de-corpo-de-delito/\#gs.NihKIUE> . Acesso em: 14 out. 2015. 
“'Por que não me respeitam?', indaga menina agredida por ser do Candomblé",53 “A Intolerância Religiosa que mata na Bahia: "queima satanás, liberta senhor, destrói a feitiçaria", 54 "Estudante é expulso de fórum por se recusar a tirar adereço do candomblé" 55 e Terreiro pede, em carta, apuração sobre finalidade dos Gladiadores do Altar. ${ }^{56}$ Frise-se que todos as manchetes aqui transcritas fazem referência a atos de intolerância e violência - psicológica e física, inclusive um que culminou com a morte de uma mãe-de-santo na Bahia - ocorridos no ano de 2015 - que não chegou a seu final ainda - e representam, somente, uma parte do espectro da intolerância religiosa.

Não há como negar o papel determinante que as pregações da Igreja Universal do Reino de Deus (IURD) possuem no recrudescimento da violência contra as religiões afro-brasileiras, contudo a intolerância religiosa não surgiu com a IURD, como se viu, trata-se, apenas, de uma modificação do agente repressor, antes a repressão acontecia por meio dos agentes estatais, em específico da polícia - simbolizado pelo Delegado Pedrito Gordo, retratado por Jorge Amado - atualmente se dá pela ação dos indivíduos particulares - simbolizados pelos fiéis da Igreja Universal do Reino de Deus - contudo, indaga-se: qual a razão em específico para se perseguir os cultos afro-brasileiros?

\section{Conclusão}

Iniciou-se o presente trabalho com explicações acerca da teoria das lutas de classe, em específico da teoria proposta pelo italiano Domenico Losurdo. Conforme ponto já anteriormente desenvolvido, para o italiano as lutas de classes possuem três configurações: a clássica que opõe proletariado à burguesia, a luta pela emancipação das nações oprimidas e a luta pela emancipação da mulher.

Ao se estudar as estruturas das religiões afro-brasileiras, verifica-se a subsunção às categorias de Losurdo. Já foi extensamente elaborado o fato de que as religiões afro-brasileiras nasceram nas senzalas da escravidão, com o fim do regime escravocrata e o início da "escravidão legal" e a total impossibilidade de ascensão social, o antigo escravo e seus descendentes tornaram-se necessariamente membros do proletariado e, com isso, configuram-se as estruturas das religiões afro-brasileiras como sendo proletárias em sua essência e origem. Em oposição ao catolicismo que à época da

53 Disponível em: $<$ http://www.geledes.org.br/por-que-nao-me-respeitam-indaga-menina-agredida-por-serdo-candomble/\#gs.GwxmS4A>. Acesso em: 14 out. 2015.

54 Disponível em: <http://www.geledes.org.br/a-intolerancia-religiosa-que-mata-na-bahia-queima-satanasliberta-senhor-destroi-a-feiticaria/\#gs.De2dBjs>. Acesso em: 14 out. 2015.

55 Disponível em: < http://www.geledes.org.br/estudante-e-expulso-de-forum-por-se-recusar-a-tirar-aderecodo-candomble/\#gs.D1P0O2E>. Acesso em: 14 out. 2015.

56 Disponível em: <http://www.geledes.org.br/terreiro-pede-em-carta-apuracao-sobre-finalidade-dosgladiadores-do-altar/\#gs.qe1RWnY>. Acesso em: 14 out. 2015. 
escravidão era a religião oficial, a religião do Estado, sendo ele um aparato necessário para a produção e reprodução do capital, uma instituição a serviço da burguesia, opondo-se, posteriormente ao Kardeccismo do início do século XX que por possuir origem francesa possuía inserção somente nas classes burguesas (daí o surgimento da Umbanda, como já explicado) e hodiernamente em oposição as Igrejas Neopentecostais, que manipulam grande parte da classe trabalhadora na defesa dos interesses e instituições burguesas.

No que tange ao aspecto da luta pela libertação dos países oprimidos, o vocábulo que qualifica a origem de tais religiosidades é suficiente para sua caracterização, afro-brasileiras. Possuem origem em duas localidades da periferia do capital, oprimidas e exploradas historicamente. De sorte que suas estruturas remetem à África, na liturgia, nos mitos, nos instrumentos e cânticos, nos Orixás, a presença Africana é notada em todos os seus aspectos. Por sua vez, a Umbanda possui aspectos marcantes da nacionalidade brasileira, como a linha dos caboclos, baianos e pretos-velhos, ademais imiscuiu-se o africano ao brasileiro, criando uma essência que é única e inconfundivelmente periférica, oprimida e explorada.

$\mathrm{O}$ aspecto mais interessante se dá na subsunção à categoria da luta pela libertação da mulher. Salvo raríssimas exceções (alguns terreiros de Candomblé na Bahia não permitem que as mulheres toquem os atabaques), não há limitação ao papel que a mulher pode desempenhar dentro do culto, destaca-se, ainda, que a maioria dos terreiros é comandada por mulheres, não há nenhum impedimento para que a mulher desenvolva sua mediunidade. Todavia, destaca-se, o papel das próprias entidades como desafiadoras do machismo e da ordem patriarcal. A pombagira é demonizada por ser mulher, dona de seu corpo e de suas vontades, por desafiar a sociedade patriarcal e machista, ocasionando relatos assustadores como o que se segue:

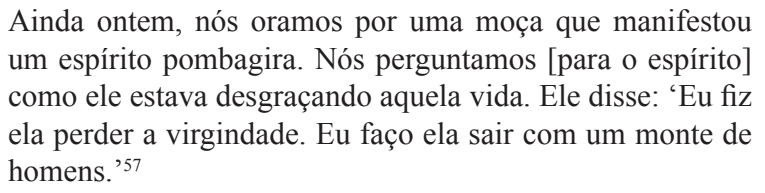

Nota-se, evidentemente, a associação entre a mulher que é livre para viver a sua sexualidade da forma que deseja, o pecado, o demônio e a pombagira. De sorte que a pombagira é uma representação da mulher livre, da mulher que não se cala ante as opressões da sociedade e que luta contra o patriarcado e o machismo por uma sociedade em que possa ser verdadeiramente livre.

57 ALMEIDA, Ronaldo de. A Igreja Universal e seus demônios. Um estudo etnográfico. São Paulo: Editora Terceiro Nome, 2009. p. 83. 
Justamente pelo fato de haver a total subsunção às categorias das lutas de classes de Domenico Losurdo que a intolerância e a perseguição às religiões afrobrasileiras foram e são constantes.

Em um primeiro momento em que a sociedade civil não exigia a total laicidade do Estado, a burguesia era livre para fazer uso do aparato estatal para perseguir essas religiões que se colocam diametralmente opostas aos seus interesses. Contudo, com o advento do Estado democrático de Direto, a queda do Regime Ditatorial Militar, houve a pressão para que o Estado efetivamente respeitasse as chamadas liberdades democráticas, dentre as quais se insere a liberdade religiosa. Razão pela qual a perseguição se retirou da esfera do Estado, criou-se uma atmosfera de pretensa liberdade e a repressão passou a ser feita por agentes particulares, representados na figura emblemática da Igreja Universal do Reino de Deus.

Configuram-se, portanto, as religiões afro-brasileiras como verdadeiros brados por liberdade: liberdade ao proletariado, liberdade às Nações oprimidas e liberdade à mulher.

Escrito no decorrer do ano de 2015 em São Paulo/SP e João Pessoa/PB.

\section{Referências}

ALMEIDA, Ronaldo de. A Igreja Universal e seus demônios. Um estudo etnográfico. São Paulo: Editora Terceiro Nome, 2009.

AMADO, Jorge. Jubiabá. Rio de Janeiro: Record, 1995.

AMADO, Jorge. O sumiço da santa. São Paulo: Cia. das Letras, 2010.

AMADO, Jorge. Tenda dos milagres. São Paulo: Cia. das Letras, 2008.

ARAÚJO, Maurício Azevedo de. Afirmando a alteridade negra e reconhecendo direitos: as religiões de matriz africana e a luta por reconhecimento jurídico: repensando a tolerância e a liberdade religiosa em uma sociedade multicultural. 2007. 120 f. Dissertação (Mestrado em Direito) - Universidade de Brasília, Brasília, 2007.

ARCARY, Valério. Um reformismo quase sem reformas. Uma crítica marxista do governo Lula em defesa da revolução brasileira. São Paulo: Editora Sundermann, 2014.

BASTIDE, Roger. O candomblé da Bahia: rito nagô. São Paulo: Cia. das Letras, 2001.

CANCELLI, Elizabeth. O mundo da violência. A polícia da era Vargas. Brasília, UNB, 1997.

CARVALHO, Leonardo Dallacqua de. O Candomblé na obra de Jorge Amado: perseguição e estratégias do culto na Bahia (1935 - 1940). In: SIMPÓSIO INTERNACIONAL DE INICIAÇÃO CIENTÍFICA DA USP (SIICUSP), 17, 2009, São Paulo: USP, 2009. 
CHALHOUB, Sidney (Org.). A História contada: capítulos de história social da literatura no Brasil. Rio de Janeiro: Nova Fronteira, 2001.

FERRÃO, Marcelo. A intolerância religiosa que mata na Bahia: "Queima essa satanás, liberta Senhor, destrói a feitiçaria". Revista Livre, Camaçari, jun. 2015.

GERMANO, Patrícia Gomes. O sumiço da santa: uma representação do híbrido literário-culturalreligioso. 2008. Dissertação (Mestrado em Literatura e Interculturalidade) - Departamento de Artes de Centro de Educação, Universidade Estadual da Paraíba, Campina Grande, 2008.

ISAIA, Artur Cesar; MANOEL, Ivan Aparecido (Org.). Espiritismo e religiões afro-brasileiras. São Paulo: Editora UNESP, 2012.

JANSA, Tomáš. Candomblé: as origens, desenvolvimento, transformações e seu papel no decorrer do tempo. Olomouc: [s.n.], 2010. Disponível em: <https://theses.cz/id/swyq85/Tom_Jansa_-_bakalsk_ prce.pdf $>$.

JENSEN, Tina Gudrun. Discursos sobre as religiões afro-brasileiras. Da desafricanização para a reafricanização. Tradução Maria Filomena Mecabô. REVER - Revista de Estudos da Religião, São Paulo, n. 1, p. 1-21, jan. 2001. Disponível em: <http://www.pucsp.br/rever/rv1_2001/index.html>.

LOSURDO, Domenico. A luta de classes: uma história política e filosófica. São Paulo: Boitempo Editorial, 2015.

LUKÁCS, György. Marxismo e teoria da literatura. São Paulo: Expressão Popular, 2010.

MARX, Karl; ENGELS, Friedrich. A ideologia alemã. São Paulo: Boitempo Editorial, 2007.

MARX, Karl; ENGELS, Friedrich. Manifesto do partido comunista. São Paulo: Penguin Classics Cia. das Letras, 2012.

MOURA, Clóvis. Sociologia do negro brasileiro. São Paulo: Editora Ática, 1988.

PRANDI, Reginaldo. Herdeiras do Axé. São Paulo: Editora Hucitec, 1996.

PRANDI, Reginaldo. Mitologia dos Orixás. São Paulo: Cia. das Letras, 2001.

RAMOS, Arthur. As culturas negras no novo mundo. São Paulo: Companhia Editora Nacional, 1979.

SANTOS, Edmar Ferreira. O poder dos candomblés: perseguição e resistência no Recôncavo da Bahia. Salvador: EDUFBA, 2009.

SANTOS, Erisvaldo Pereira dos. A educação e as religiões de matriz africana: motivos da intolerância. In: ANAIS DA 28. REUNIÃO DA ANPED. GT Afro-Brasileiros e Educação, p. 01-17. Caxambu: ANPED, 2005. Disponível em: <http://28reuniao.anped.org.br/textos/gt21/gt21241int. doc $>$.

SANTOS, Rosana dos. Por todos os santos: o sincretismo religioso na obra Tenda dos Milagres de Jorge Amado. 2011. Monografia (Licenciatura Plena em Letras) - Faculdades Integradas Campo- 
Grandenses, Fundação Educacional Unificada Campograndense, Rio de Janeiro, 2011. Disponível em: <https://issuu.com/casadejorgeamado/docs/trabalho_monografico_finalizado>.

SHARPE, Jim. A história vista de baixo. In: BURKE, Peter (Org.). A escrita da história: novas perspectivas. Tradução de Magda Lopes. São Paulo: Editora UNESP, 1992.

SILVA, Francisco Thiago. Candomblé Iorubá: a relação do homem com seu orixá pessoal. Último Andar - Cadernos de Pesquisa em Ciência da Religião, São Paulo, n. 21, p. 48-73, 2013. Disponível em: <http://revistas.pucsp.br/index.php/ultimoandar/article/view/13984/10290>.

SILVA, Vagner Gonçalves da. Exu. O guardião da casa do futuro. Rio de Janeiro: Editora Pallas, 2015. VERGER, Pierre Fatumbi. Notas sobre o culto aos orixás e voduns na Bahia de Todos os Santos, no Brasil, e na Antiga Costa dos Escravos, na África. 2. ed. São Paulo: Editora da Universidade de São Paulo, 2000.

VERGER, Pierre Fatumbi. Orixás - deuses iorubás na África e no Novo Mundo. Tradução de Maria Aparecida da Nóbrega. Salvador: Corrupio, 1996. 
